\title{
36. LATE CENOZOIC SEDIMENTARY FACIES AND PROCESSES IN THE IBERIAN ABYSSAL PLAIN, SITE 637, ODP LEG 103'
}

\author{
María C. Comas, Instituto Andaluz de Geologia Mediterránea, C.S.I.C., Universidad de Granada, Campus \\ Universitario de Fuentenueva, Granada, Spain \\ and \\ Andrés Maldonado, Instituto de Ciencias del Mar, C.S.I.C., Paseo Nacional, Barcelona, Spain
}

\begin{abstract}
The late Cenozoic deposits recovered at ODP Site 637 from the Iberian Abyssal Plain near the continental margin off northwestern Spain include three main facies groups. Turbidites are the dominant facies association (two-thirds of the total thickness), followed by pelagites (one-fourth), and subordinate amounts of contourites (one-tenth). Slump deposits occur locally in the upper Miocene and middle Pliocene. Turbidity currents and pelagic settling were the significant sediment depositional processes from the Pliocene to the Pleistocene, whereas bottom currents predominated during the late Miocene.

Fine-grained, base-cut-out turbidites, normally starting with the $\mathrm{T}_{d}$ division, are the most abundant sequence type. The pelagites include both carbonate-rich pelagic and hemipelagic facies. The two types of contourites, sandy and calcareous-rich or fine-grained terrigenous, record two types of bottom-current processes.

The Cenozoic deposits at Site 637 show a general upward transition from contourites in the upper Miocene to turbidites in the Pliocene-Quaternary. The entire section is rhythmically bedded and has a poorly developed cyclic pattern defined by variations in the total carbonate content. The low sedimentation rates also show the same cyclicity, with lower values for the late Miocene and late Pliocene. This evolution reflects the predominant depositional processes and the dissolution of carbonates by a lower CCD during the late Miocene.
\end{abstract}

\section{INTRODUCTION}

Site 637 contains the most complete Cenozoic section recovered during Ocean Drilling Program (ODP) Leg 103 from the northwestern Iberian continental margin. The site is on the boundary between the Iberian Abyssal Plain and the continental rise, on the eastern flank of a buried, northward-trending basement ridge close to the boundary between oceanic and continental crust (Fig. 1). Although the main objective at Site 637 was to core the ridge and verify whether peridotites of the type dredged from Hill 5100 were present (Boillot et al., 1980), the recovery of sediments overlying the peridotite allows us to describe the Cenozoic section of the distal Iberian margin.

On the most distal sector of the morphologically complex Galicia margin, the Cenozoic sediments are thin and discontinuous (Boillot, Winterer, et al., 1987). These strata form a ponded sequence that was deposited during the most recent post-rift evolution of the margin, and they fill the half-grabens remaining after the syn-rift and early post-rift sedimentation. The top of the basal Mesozoic syn- and post-rift macrosequence, which records several diastrophic events in the early evolution of the continental margin, is represented by a major diacronous Paleogene to Pleistocene unconformity (Fig. 1). Acoustic basement, consisting of the underlying Mesozoic formations, continental basement, and peridotite, crops out at several fault escarpments on the margin (Mougenot et al., 1985; Boillot et al., this volume).

The sites drilled during Leg 103 are in a region that appears to be relatively undisturbed by Cenozoic deformation. The fault escarpments observed in the area are inherited from the Mesozoic rifting stage of the margin (Boillot et al., 1979). At Site 637 , the Cenozoic section on top of the basement peridotite is

${ }^{1}$ Boillot, G., Winterer, E. L., et al., 1988. Proc. ODP, Sci. Results, 103: College Station, TX (Ocean Drilling Program).
$212 \mathrm{~m}$ thick and was deposited from the late Miocene to Recent (except for the lowermost $35 \mathrm{~m}$, which is of Paleocene-Eocene age, based on ichthyoliths; Doyle, this volume). This reduced sedimentary section reflects the starved nature of the margin in this region.

Cenozoic sediments on the northwestern Iberian margin were previously recovered during Deep Sea Drilling Project (DSDP) Leg 47B (Site 398; Shipboard Scientific Party, 1979). The deposits of the thicker Cenozoic section $(800 \mathrm{~m})$ drilled at Site 398 are lithologically complex and record a multitude of sedimentary processes. The upper Miocene to Pleistocene deposits are $326 \mathrm{~m}$ thick and consist mainly of cyclic alternations of pelagic and hemipelagic clayey carbonate sediments. Evidence for bottom-current activity also occurs throughout the entire section (Maldonado, 1979). In contrast, the sequence cored at Site 637 consists mostly of rhythmic alternations of turbidites, pelagics, and contourites, predominantly terrigenous and without a welldefined cyclicity (see "Site 637" chapter; Shipboard Scientific Party, 1987). The differences between these two sections may be attributed to the contrasting environmental parameters controlling sedimentation on the abyssal plain (Site 637) and upper margin (Site 398) depositional settings. More similar to the Site 637 deposits is the Cenozoic section at Site 118 in the Bay of Biscay (Shipboard Scientific Party, 1972a), which is composed of Paleocene and Eocene brown clays overlain by Miocene to Pleistocene turbidites and pelagic sediments.

In this paper we describe the Miocene to Pleistocene facies types recovered at Site 637 and summarize the principal results of our petrographic and sedimentologic analyses. We also attempt to identify the nature of the depositional mechanisms and environmental factors that may have controlled sedimentation during the late Cenozoic in this sector of the eastern North Atlantic. We suggest sedimentologic criteria to differentiate between turbidity and bottom-current processes in the deep-water facies. Finally, we discuss reasons for the large proportion of pelagic biogenic deposits found throughout the stratigraphic 
A

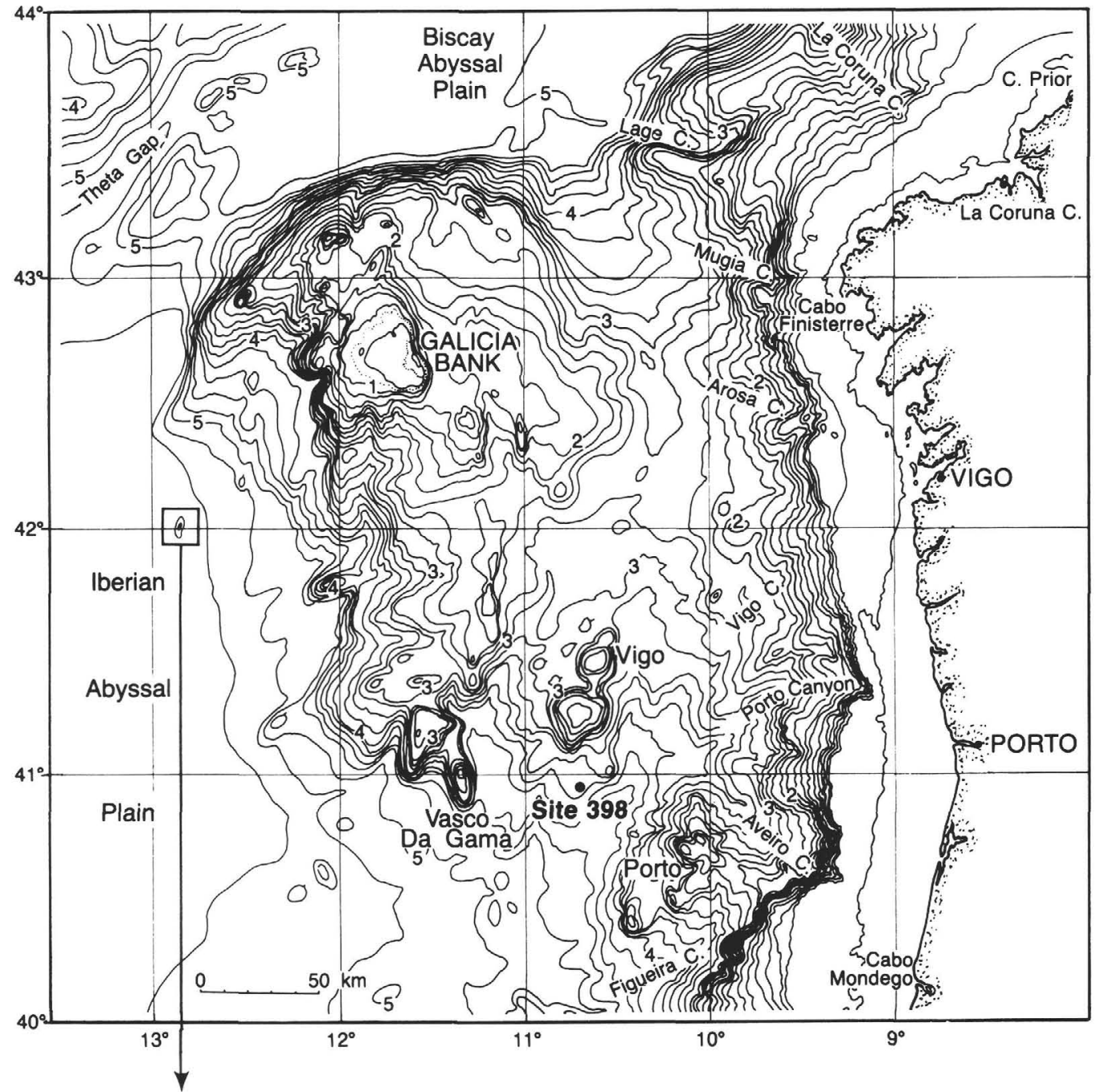

B

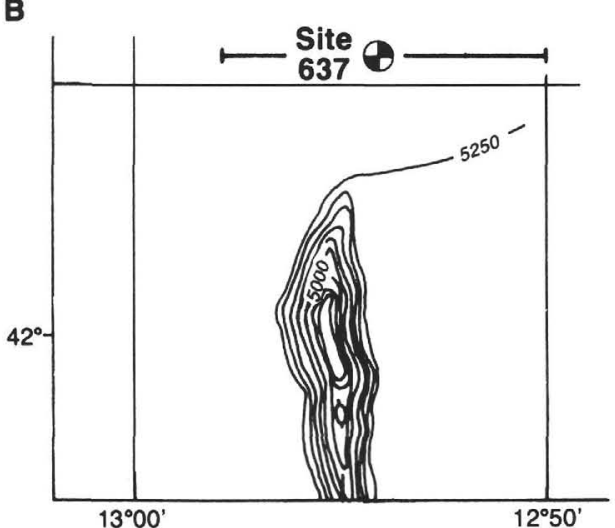

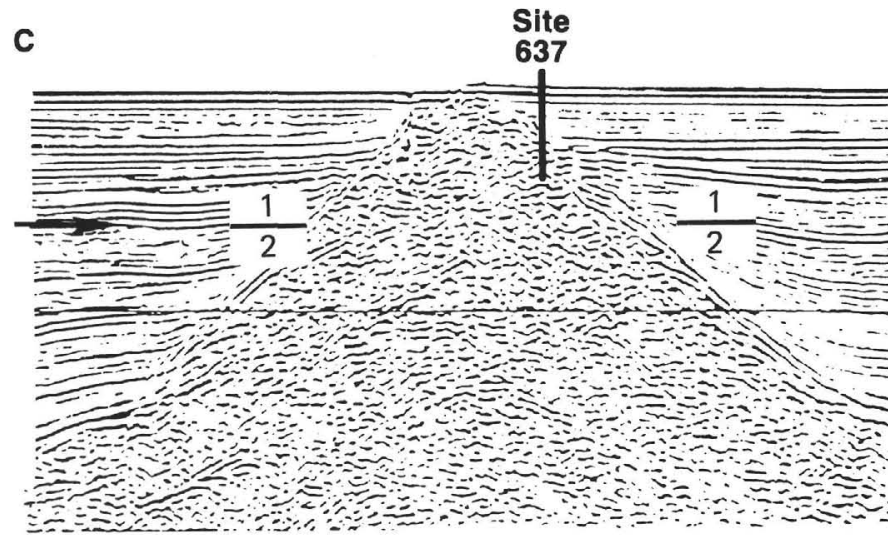

C

Figure 1. A and B. Bathymetric map showing location of ODP Site 637 on the Galicia margin. C. Seismic line B9 crossing Site 637. Seismic sequences 1 and 2 correspond to the seismic units defined by Shipboard Scientific Party (1979).

section, in spite of a postulated depositional water depth close to the level of the carbonate compensation depth (CCD).

\section{METHODS}

The cores were visually described both aboard the JOIDES Resolution and at the ODP Repository at Lamont-Doherty Geological Observatory. Detailed logs of sediment types and facies were established ac- cording to standard procedures. A total of 113 samples from the upper Cenozoic sedimentary section were chosen for post-cruise analyses (Appendix A). These samples were selected as representative of the different sediment facies and sequences, in sections without visible core disturbance or major bioturbation.

Sediment texture was analyzed with a large-diameter settling tube for the coarse-grained fraction ( $>50 \mu \mathrm{m})$ and a Sedigraph 5000D for the silt and clay fraction (Giró and Maldonado, 1985). The settling tube 
is a modified version of the instrumentation described by Nelsen (1976). The Sedigraph determines the size distribution of sediment particles dispersed in water by the attenuation of a fine collimated X-ray beam as a function of time and height. The grain size distribution, statistical parameters, cumulative curve, and histogram for each sample were calculated with a computer program integrating the results of the settling tube and Sedigraph (Giró and Maldonado, 1985).

The composition and preservation of microfossils in the fraction coarser than $50 \mu \mathrm{m}$ were determined with a stereographic microscope and SEM at low magnification $(100 \times$ to $500 \times)$. Benthic/planktonic foraminifer and terrigenous/biogenic ratios were determined by counting 300-400 grains. The fine silt and clay fractions were examined with the SEM at high magnification $(3000 \times$ to $10,000 \times)$ to determine calcareous nannofossil preservation.

Total carbonate content was determined in bulk samples using a modified Bernard calcimeter with the usual gas volumetric procedure. Alkali elements and heavy metal $(\mathrm{Ca}, \mathrm{Mg}, \mathrm{Sr}, \mathrm{Fe}, \mathrm{Mn}, \mathrm{Ni}, \mathrm{Cu}, \mathrm{Pb}$, and Co) concentrations were determined for 24 selected samples. The samples were leached with acid to extract the metals. Two grams of the bulk sample was digested in $5 \mathrm{~cm}^{3}$ of hydrochloric acid $(75 \% \mathrm{HCl}$ and $25 \%$ $\mathrm{HNO}_{3}$ ) to dissolve carbonates, authigenic minerals, and organic matter; the silicates are not affected by this treatment (Agemian and Chan, 1976). Metal concentrations were determined using standard atomic absorption spectrophotometer techniques with heater graphite atomizer (Appendix B). Standard solutions were prepared with metal concentrations close to the mean quantities in the sample solution (Carmody et al., 1973).

\section{LITHOLOGY AND AGE}

The 212-m-thick Cenozoic section cored at Site 637 is divided into three lithologic units (see "Site 637" chapter; Shipboard Scientific Party, 1987). Lithologic Unit I (0-135. 0 m below seafloor-mbsf) is divided into three subunits for descriptive purposes, although similar sediment types exist throughout. The uppermost lithologic Subunit IA (0-44.9 mbsf) contains Holocene to lower Pleistocene gray calcareous clay and marl. Subunit IA was poorly recovered, found only in the core catchers of Cores 103-637A-1R to 103-637A-5R. These sediments are not described because of the sparsity of recovered material.

Lithologic Subunit IB (44.9-83.7 mbsf) is characterized by alternations of light-colored foraminifer-bearing nannofossil ooze, clayey ooze, and marl and gray to dark gray calcareous clay, silty clay, and clayey silt. There are scattered silty fine-sand layers; indications are that some of the silt and fine sand may have been washed out by drilling. These sediment types typically occur as couplets, with silts at the bottom of the couplet grading upward to clay and capped by the more calcareous, light-colored sediments. In these couplets, the coarser grained layers show sedimentary structures characteristic of fine-grained (muddy) turbidites (Stow and Shanmugam, 1980). The biogenic calcareous deposits are homogenous and mostly structureless; where present, bioturbation blurs the depositional contacts. Calcareous beds of white foraminiferal sand occur in Cores 103-637A$7 \mathrm{R}$ and $103-637 \mathrm{~A}-8 \mathrm{R}$. These foraminifer sands are structureless or show normal to reverse grading; contacts with the overlying and underlying sediment are either sharp or gradational. Subunit IB is early Pleistocene in age.

Lithologic Subunit IC (83.7-135.0 mbsf) consists of lower Pleistocene to upper Pliocene sediments that are distinguished from Subunit IB because they contain less numerous thick turbidites and fewer and thinner $(<5 \mathrm{~cm})$ silty basal layers. A slight color and lithology change occurs at Core 103-637A-12R at the Pleistocene/Pliocene boundary. At this level, a bioturbated, light olive to grayish brown marl unit overlies a gray clay on top of gray mud turbidite layers. Diffuse manganese-rich laminae and blebs occur in the calcareous layers throughout the subunit. The turbidite cycles are thicker, and the basal silty layers are up to $15 \mathrm{~cm}$ thick in Section 103-637A-15R-1.
Unit II (upper Pliocene to upper Miocene, 135.0-181.3 mbsf) consists of slumped brown clay and nannofossil marl. Slump intervals occur in Sections 103-637A-15R-3, 103-637A-16R-1 to 103-637A-19R-1, and 103-637A-19R-2. The slumped sediments consist dominantly of light-colored nannofossil ooze, clayey nannofossil ooze, calcareous clay, variegated marl, and brown clay, with minor silty layers. Turbidites interbedded with minor marl appear below the uppermost slump (Section 103-637A17R-1 to Sample 103-637A-17R-2, $6 \mathrm{~cm}$ ). The turbidite couplets $(15-20 \mathrm{~cm}$ thick) consist of dark gray silt grading upward to gray or olive-gray clay. These sediments overly a 5.5-m-thick interval (Sections 103-637A-17R-2 to 103-637A-17R, CC) in which the dominant sediment types are strongly bioturbated white nannofossil ooze interbedded with olive marl, with subordinate amounts of foraminifer sand similar to that found in lithologic Unit I. A drastic change in lithology occurs at 160.7 mbsf (Sample 103-637A-18R-1, 0 cm). Below this depth, the lower part of Unit II (lowermost Pliocene to upper Miocene) is characterized by interbedded bioturbated and mottled brown clay and variegated calcareous clay, white nannofossil ooze, and white foraminifer sand. Clay comprises about $85 \%$ of this part of Unit II.

Lithologic Unit III (181.3-212.0 mbsf) overlies basement and consists of unfossiliferous, diffusely banded, brown to reddish, mottled clay. Mn-oxide-rich dark specks and dispersed detrital grains are common. The shipboard party interpreted these sediments to be a mixture of zeolite-rich pelagic clay, continental material (brought to the site by contour currents as a nepheloid layer, or in the "tails" of turbidity currents), and weathering products from the underlying peridotite (Shipboard Scientific Party, 1987). Similar brown clays were also sampled on Leg 103 at Sites 640 and 639 (Meyer and Davies, this volume) and on DSDP Leg 12 in the Bay of Biscay (Sites 118 and 119; Shipboard Scientific Party, 1972a, 1972b).

\section{FACIES TYPES AND DEPOSITIONAL PROCESSES}

Three main facies groups are differentiated in the upper $\mathrm{Ce}$ nozoic section recovered at Site 637 . These sediments show a large variety in sediment texture, composition, and sedimentary structure. The characteristics that are most diagnostic in the definition of these facies types include (1) grain size distribution, (2) sedimentary structures, and (3) location within sedimentary sequences. Both the composition of the deposits and the proportions of terrigenous vs. biogenic components are similar in sediment types attributed to different depositional processes. The biogenic constituents show significant differences in composition and degree of preservation between the major facies groups (Tables 1 and 2).

The three major depositional processes (and corresponding facies groups) identified at Site 637 are (1) differential pelagic settling (pelagites and hemipelagites), (2) turbidity currents (turbidites), and (3) bottom currents (contourites). A few beds are attributed to slumps.

\section{Identification of Facies Types}

\section{Pelagic and Hemipelagic Facies}

The pelagic and hemipelagic facies type encompasses a wide spectrum of calcareous oozes and marls. The more pelagic endmember of this facies consists of white calcareous, foraminiferrich, nannofossil ooze. The mixed terrigenous-biogenic hemipelagic end-member includes light-colored, clayey, calcareous nannofossil ooze and marl. The primary source for these deposits is pelagic biogenic material; sedimentation represents a complex balance between primary productivity, terrigenous input, and dissolution (Berger, 1974). Terrigenous supply, from the transfer 


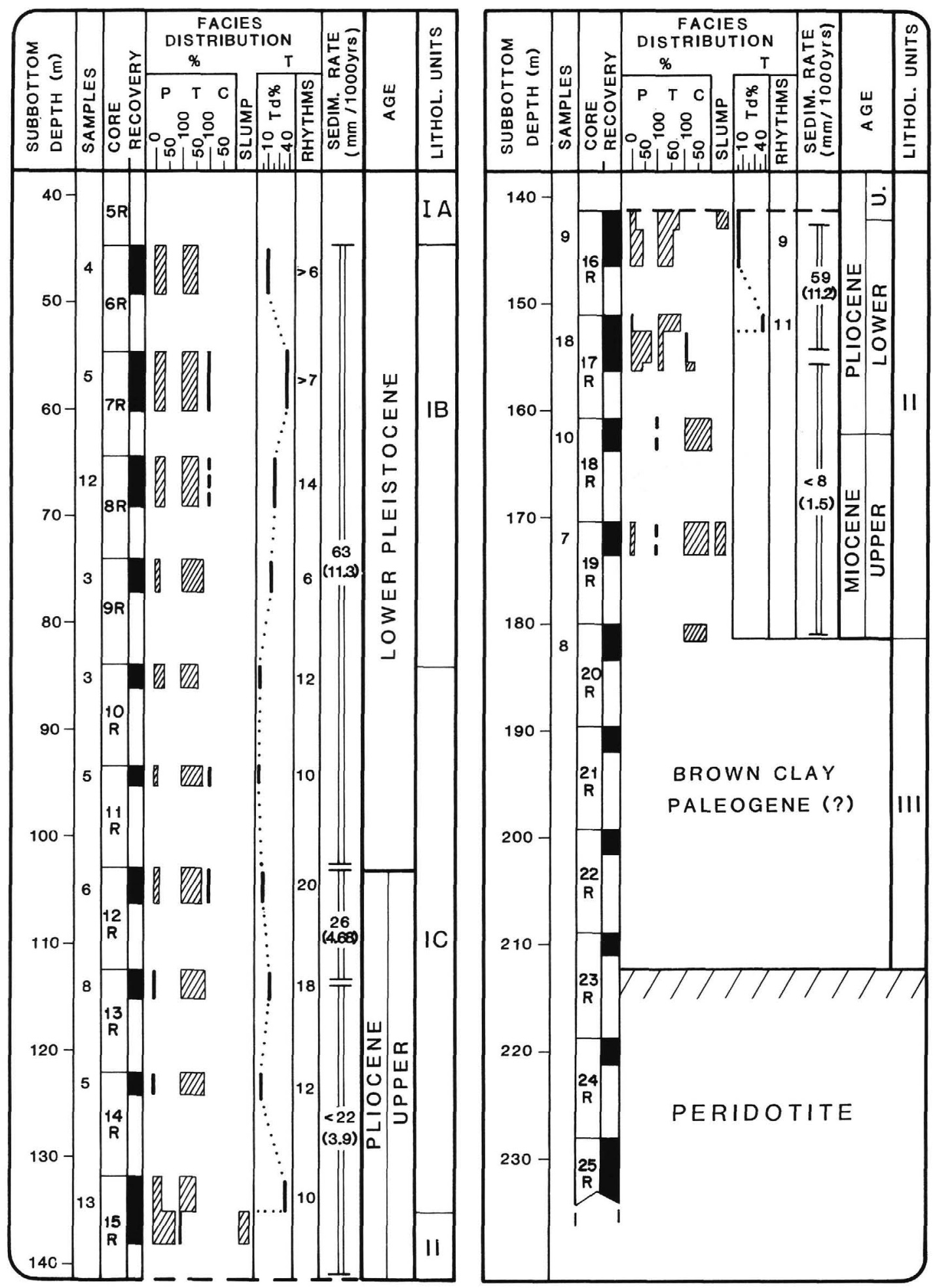

Figure 2. Stratigraphic log of deposits recovered at Site 637, showing facies distribution and sedimentation rates in the upper Cenozoic section. Numbers in parentheses in sedimentation rate column are accumulation rates in $\mathrm{g} / \mathrm{cm}^{2}$. Symbols as in Table 1. The number of analyzed samples from each core is indicated.

of fine sediment to deep water, is a major control of clay content (Gorsline, 1984). Red pelagic clays are not recognized at Site 637 in the upper Cenozoic section.

\section{Turbidite Facies}

The turbidite facies are dark-colored silt and mud turbidites consisting of terrigenous and terrigenous-biogenic sediments.
Typically, each turbidite layer is normally graded and displays the classical sequence of structures described for fine-grained turbidites (Piper, 1978; Stow, 1979; Stow and Shanmugam, 1980; Stow and Bowen, 1980). Fine-grained turbidite sedimentation is well documented in the literature (see Stow and Piper, 1984). The interbedded silt and mud laminae generally present in these turbidites are believed to be the result of depositional sorting of 
Table 1. Lithologic descriptions of the subfacies. Terminology for sand-silt-clay sediment mixtures after Shepard (1954). Symbols: $P=$ biogenic pelagite; $F=$ hemipelagite; $T_{c}, T_{d}$, and $T_{e 1}-T_{e 3}=$ turbidite sequence divisions; $\mathbf{F C}=$ foraminifer contourite; $\mathrm{SC}=$ silt contourite; $\mathrm{MC}=$ mud contourite; $\mathbf{C C}=$ clay contourite.

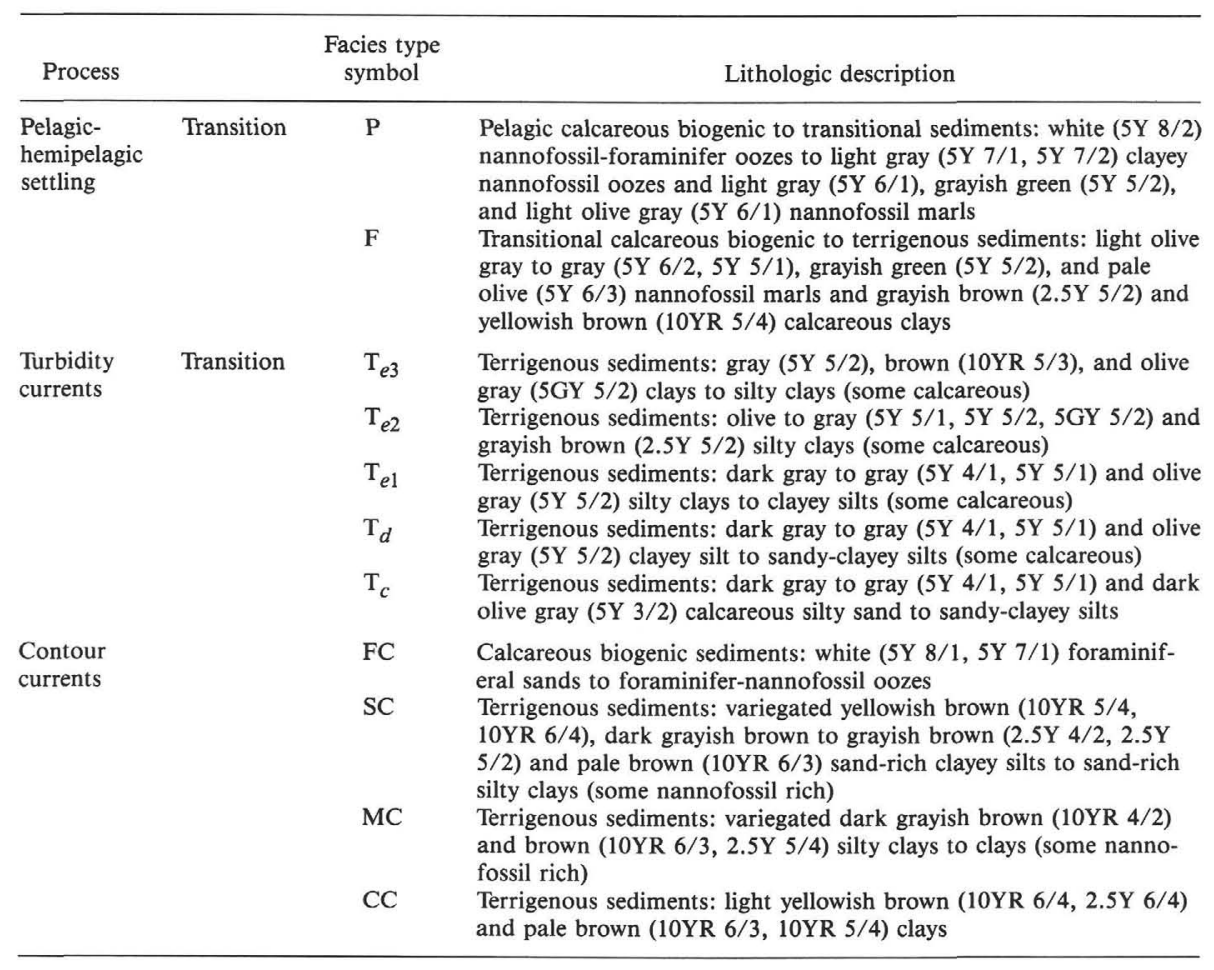

Table 2. Textural and compositional data for each of the subfacies identified. Facies type symbols as in Table 1. The values for the ranges were selected from uncontaminated and unbioturbated samples. Preservation: $\mathbf{G}=\operatorname{good} ; \mathbf{M}=$ moderate; $\mathbf{P}=$ poor.

\begin{tabular}{|c|c|c|c|c|c|c|c|c|c|c|c|c|}
\hline \multirow[b]{2}{*}{$\begin{array}{l}\text { Sediment } \\
\text { type }\end{array}$} & \multirow[b]{2}{*}{$\begin{array}{l}\text { Facies } \\
\text { type }\end{array}$} & \multicolumn{7}{|c|}{ Texture } & \multicolumn{2}{|c|}{ Sand fraction } & \multicolumn{2}{|c|}{ Preservation } \\
\hline & & $\begin{array}{c}\mathrm{CaCO}_{3} \\
(\%)\end{array}$ & $\begin{array}{l}\text { Sand } \\
(\%)\end{array}$ & $\begin{array}{l}\text { Silt } \\
(\%)\end{array}$ & $\begin{array}{l}\text { Clay } \\
(\%)\end{array}$ & $\begin{array}{c}\text { Mean } \\
(\phi)\end{array}$ & $\begin{array}{l}\text { Sorting } \\
(\phi)\end{array}$ & $\begin{array}{l}\text { Skewness } \\
(\phi)\end{array}$ & $\begin{array}{c}\text { Terrigenous } \\
\text { and biogenic }\end{array}$ & $\begin{array}{l}\text { Benthic/planktonic } \\
\text { foraminifers }\end{array}$ & Foraminifers & Nannofossils \\
\hline $\begin{array}{l}\text { Biogenic } \\
\text { pelagites }\end{array}$ & $\mathrm{P}$ & $43.9-82.7$ & $0.22-9.88$ & $11.0-27.5$ & $69.6-87.4$ & $10.6-9.34$ & $2.90-1.85$ & $0.29-0.18$ & $0-0.6$ & $1-0.03$ & G-M & G-M \\
\hline $\begin{array}{l}\text { (Hemi) } \\
\text { Pelagites }\end{array}$ & $\mathrm{F}$ & $15.8-46.7$ & $0.03-2.66$ & $20.0-23.2$ & $67.6-79.5$ & $10.5-10.1$ & $3.31-2.60$ & $0.24-0.12$ & $0-4$ & $1-0.09$ & G-M & M \\
\hline Turbidites & $\begin{array}{l}\mathrm{T}_{e 3} \\
\mathrm{~T}_{e 2} \\
\mathrm{~T}_{e 1} \\
\mathrm{~T}_{d} \\
\mathrm{~T}_{c}\end{array}$ & $\begin{array}{r}4.4-16.4 \\
10.5-18.9 \\
15.6-22.6 \\
6.04-20.2 \\
15.7-17.9\end{array}$ & $\begin{array}{l}0.00-0.27 \\
0.05-1.09 \\
0.70-8.65 \\
1.19-14.4 \\
27.1-52.0\end{array}$ & $\begin{array}{l}17.1-29.9 \\
20.0-37.9 \\
42.0-44.3 \\
49.9-68.4 \\
29.5-42.6\end{array}$ & $\begin{array}{l}69.8-82.9 \\
61.8-78.9 \\
46.1-57.2 \\
24.9-45.0 \\
18.5-30.5\end{array}$ & $\begin{array}{l}10.8-10.2 \\
10.4-9.8 \\
9.42-8.34 \\
9.14-6.69 \\
7.22-6.05\end{array}$ & $\begin{array}{l}3.33-2.75 \\
3.45-3.26 \\
4.13-3.62 \\
3.88-2.72 \\
3.54-2.96\end{array}$ & $\begin{array}{l}0.19--0.21 \\
0.24--0.12 \\
0.24-0.12 \\
0.62-0.25 \\
0.84-0.55\end{array}$ & $\begin{array}{l}4-17 \\
3-49 \\
4-19 \\
3-\infty \\
1-3\end{array}$ & $\begin{array}{l}0.1-0.7 \\
0.2-0.4 \\
0.1-0.8 \\
0.1-0.7 \\
0.1-0.6\end{array}$ & $\begin{array}{l}\text { G-P } \\
\text { G-P } \\
\text { G-P } \\
\text { G-P } \\
\text { G-P }\end{array}$ & $\begin{array}{l}\bar{M} \\
\mathrm{M} \\
- \\
-\end{array}$ \\
\hline Contourites & $\begin{array}{l}\text { FC } \\
\text { SC } \\
\text { MC } \\
\text { CC }\end{array}$ & $\begin{array}{l}55.2-76.0 \\
12.1-20.4 \\
8.28-15.8 \\
5.44-14.3\end{array}$ & $\begin{array}{l}27.0-53.0 \\
5.93-13.3 \\
0.73-5.06 \\
0.29-1.44\end{array}$ & $\begin{array}{l}17.2-39.1 \\
17.4-45.5 \\
12.2-42.4 \\
9.11-15.0\end{array}$ & $\begin{array}{l}22.4-39.1 \\
41.4-73.6 \\
53.8-87.3 \\
83.6-90.3\end{array}$ & $\begin{array}{l}7.42-5.35 \\
9.86-7.95 \\
11.1-9.15 \\
11.2-10.9\end{array}$ & $\begin{array}{l}4.65-3.51 \\
4.14-3.78 \\
4.02-2.81 \\
2.99-2.69\end{array}$ & $\begin{array}{l}0.43-0.30 \\
0.00--0.08 \\
0.00--0.21 \\
0.00--0.24\end{array}$ & $\begin{array}{c}0-0.1 \\
6-9 \\
11-49 \\
0.5-0.6\end{array}$ & $\begin{array}{l}0.1-0 \\
0.1-0.3 \\
0.6-4 \\
0.2-0.8\end{array}$ & $\begin{array}{l}\text { M-P } \\
P \\
P \\
P\end{array}$ & $\begin{array}{l}\text { M-P } \\
P \\
P \\
P\end{array}$ \\
\hline
\end{tabular}

silt grains from clay flocs as a result of increased shear in the bottom boundary layer (Stow and Bowen, 1978).

\section{Contourite Facies}

We recognize two sediment types at Site 637 that can be attributed to bottom-current processes: carbonate contourites and terrigenous contourites. The carbonate contourites consist of light-colored foraminiferal sands and white foraminifer-nannofossil oozes. The terrigenous contourites can be further differentiated into silt, mud, and clay types on the basis of textural composition and are all typical of Stow and Piper's (1984) "muddy contourites" facies. At Site 637 , we do not recognize a distinct contourite type sequence, and the sedimentary features do not show a consistent pattern. Moreover, the sedimentary characteristics of some beds we label as contourites are not con- clusive, and some of the evidence is based on the lack of specific sedimentary features normally observed in turbiditic or pelagic facies. Bottom-current activity, however, may be envisaged at Site 637 from the erosional structures, compositional and textural characteristics, and low sedimentation rates, as reported from many examples in the North Atlantic (Stow, 1982; Stow and Lovell, 1979; Stow and Holbrook, 1984).

\section{Facies Description and Interpretation}

\section{Calcareous Biogenic Pelagites}

The biogenic pelagites recovered at Site 637 include structurally homogenous, highly bioturbated, white to light gray nannofossil ooze, clayey nannofossil ooze, and nannofossil marl (Table 1). The samples of this facies analyzed from Subunit IB 
are predominantly composed of clay-size material (70\%-80\%), with a bimodal distribution centered at $4 \mu \mathrm{m}$ and a small mode at $100 \mu \mathrm{m}$ (Figs. 3 and 4). Total carbonate content is normally high $(64 \%-83 \%)$, except for a few samples with a relatively low content $(44 \%)$. The sand fraction $(3 \%-10 \%)$ is composed of planktonic foraminifer tests, which are normally well preserved (Table 2).

In Subunit IC these sediments have a lower total carbonate content than in Subunit IB and are composed of clayey ooze and nannofossil marl (40\%-64\% total carbonate), light colored at the top and olive-gray at the base of the subunit. The grain size distribution is very similar in the samples analyzed (Fig. 4); the clay size fraction is greater than $81 \%$, with a unimodal distribution centered at about $1.5 \mu \mathrm{m}$. This clay fraction consists mostly of well-preserved nannoplankton. The sand fraction is small $(0.2 \%-1.1 \%)$ and consists mostly of poorly preserved planktonic foraminifer tests, although benthic foraminifers and terrigenous components are more abundant than in Subunit IB (PI. 1, Fig 1.). The interval between Cores 103-637A-12R and 103-637A-14R shows the poorest foraminifer preservation.

In the uppermost part of Unit II, the pelagites included in the slumps are similar in texture and composition to the pelagic deposits of Subunit IC (Figs. 4 and 5). From Sections 103-637A17R-2 to 103-637A-17R, CC, there are beds of light-colored, clayey nannofossil ooze attributed to pelagic deposition. In these intervals, the grain size distribution is unimodal, with about $80 \%$ clay. Carbonate content is high $(60 \%-74 \%)$ (Pl. 2, Fig. 1). The sand fraction is very small $(<1 \%)$ and consists of terrigenous ( $<25 \%$ of the sand fraction) and biogenic components, most of which are well-preserved planktonic foraminifers.
Pelagite beds generally occur on top of turbidite layers overlying the $F$ division (see the following text; Fig. 6). These beds also appear intercalated with contourites (Figs. 7 and 8).

The pelagites are characterized in statistical factor analysis by a strong correlation between high total carbonate content and high $\mathrm{Ca}$ and $\mathrm{Sr}$ (Fig. 9). This reflects the large percentage of calcareous biogenic components (largely planktonic foraminifers and nannofossils) in these deposits and the preferential concentration of $\mathrm{Sr}$ in these organisms.

\section{Turbidites}

Three textural sediment types are recognized within this facies: mud, silt, and silty sand. The sediment types are usually gradational, and different lithologic categories are established on the basis of texture and sedimentary structures. The base of the silt beds is usually sharp and erosional, locally displaying scour and fill structures. Turbiditic sand layers were not recovered in the cores, although sand beds may have been washed out of the core barrel during drilling operations, as demonstrated by the presence of sand in the core liners (Shipboard Scientific Party, 1987). Silt is the most typical sediment type forming the base of the turbidite beds. It is characterized by parallel or, less commonly, low-angle oblique lamination. Turbidite muds are characterized by a delicate basal lamination and are generally bioturbated (Table 1 and Fig. 3). Total carbonate content varies between $4.5 \%$ and $20 \%$ (Table 2); the lowest values usually occur in the silt beds or at the top of the turbidite muds. In the silty sediments the sand-sized grains are predominantly terrigenous, consisting of quartz, mica, and minor heavy minerals and feldspar (Pl. 1, Figs. 3 and 6).

\section{CLAY (100 \%)}

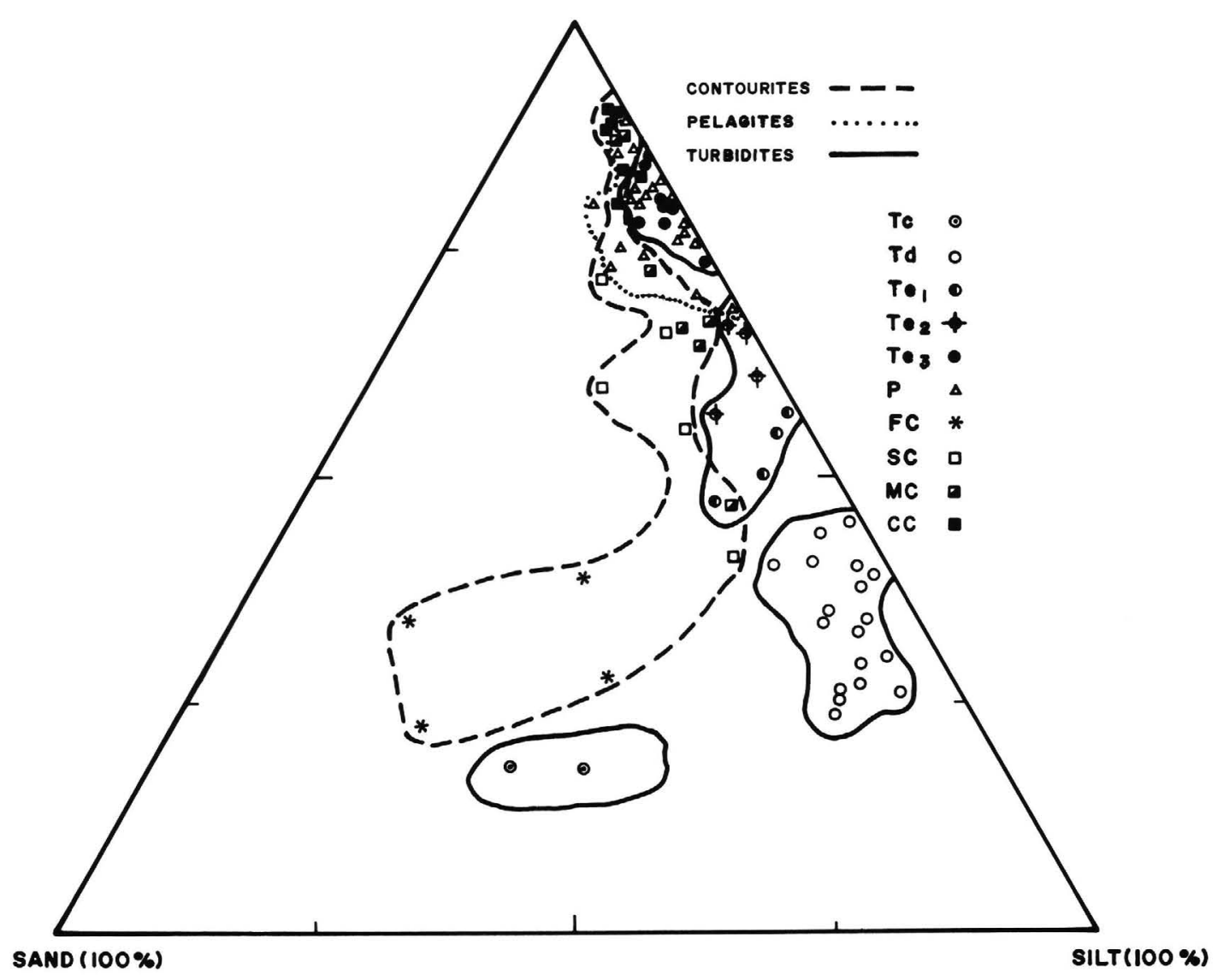

Figure 3. Triangular plot of grain size parameters of facies identified in this paper. Symbols as in Table 1. 

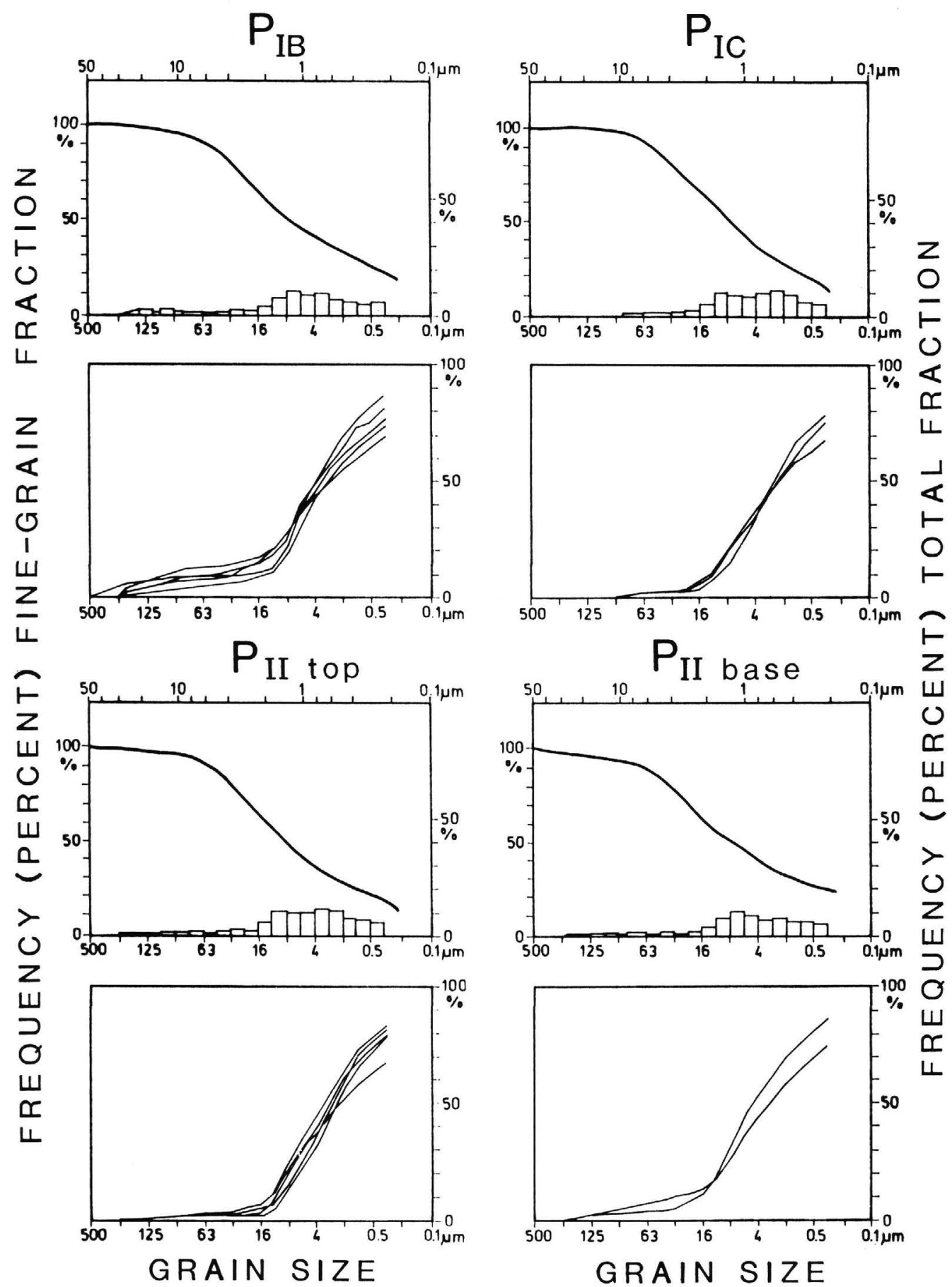

Figure 4. Cumulative curves and frequency histograms of pelagites in Subunits IB and IC and at the top and base of Unit II. A distribution histogram of the total grain size distribution and a Sedigraph cumulative curve of the fine-grained $(<50 \mu \mathrm{m})$ size fraction are shown for one representative sample from each unit. The lower diagram of each unit pair corresponds to the cumulative curve of the total grain size distribution of all the samples analyzed in the unit.

The fine-grained turbidites recovered at Site 637 can be compared with Piper's (1978) or Stow and Shanmugam's (1980) structural divisions for turbidite muds. These facies correspond to Piper's (1978) $\mathrm{T}_{d}$ (silts) and $\mathrm{T}_{e 1}, \mathrm{~T}_{e 2}$, or $\mathrm{T}_{e 3}$ divisions (muds), although every division of the sequence is not always recognizable. The turbidites generally start with the $\mathrm{T}_{d}$ division, and only a few beds show the Bouma $\mathrm{T}_{c}$ division (Figs. 6-8). Grain size analysis of these turbidites shows many similarities with the grain size distribution of fine-grained turbidites described by Kranck (1984). Factor analysis of the geochemical parameters shows that the turbidites are characterized by low concentrations of heavy metals, which correlate directly with high silt contents and relatively low carbonate content (Fig. 9). A few samples, however, show a tendency toward $\mathrm{Fe}$ and Mn enrichment. The finer-grained deposits, with a higher clay content, show higher concentrations of $\mathrm{Ni}, \mathrm{Pb}$, and $\mathrm{Co}$. 


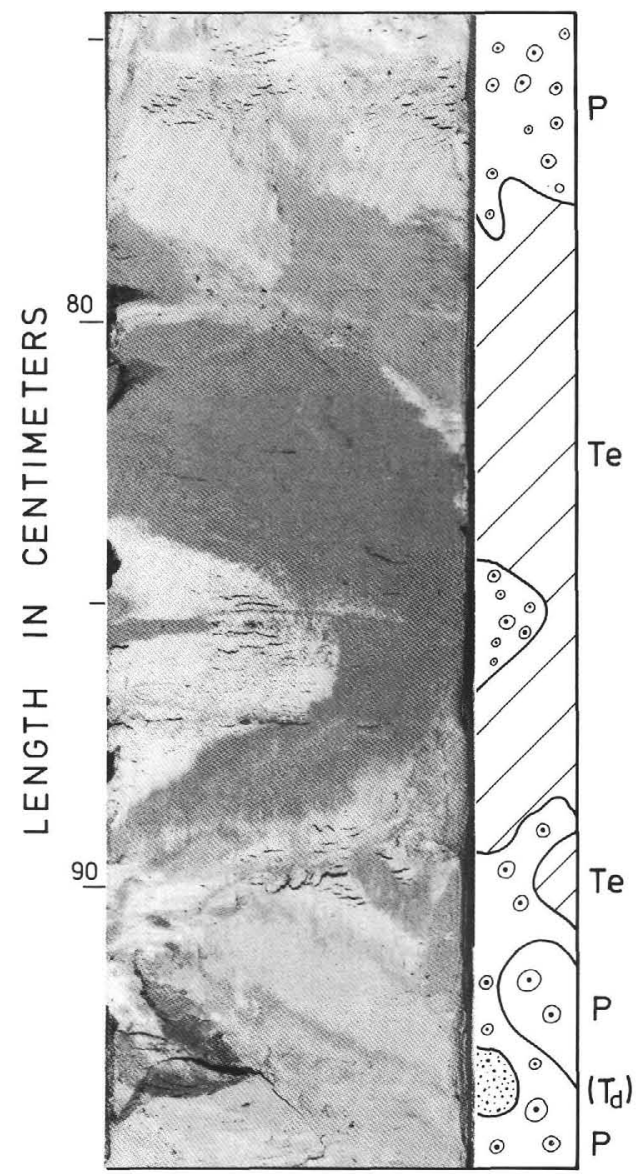

Figure 5. Slumped deposits, including pelagites and turbidite facies. Sample 103-637A-15R-3, 75-95 cm. Upper Pliocene. Symbols as in Table 1.

\section{$T_{c}$ Division}

Two samples attributed to the $\mathrm{T}_{c}$ division were analyzed (Samples 103-637A-8R-3, 56-58 cm, and 103-637A-15R-2, 115-117 $\mathrm{cm}$ ). These samples are silty sands and sandy clayey silts, according to the triangular diagram of Shepard (1954), with a mode at $63 \mu \mathrm{m}$ and long tails toward the fine-grained fractions (Table 2). The size distributions are positively skewed (Fig. 10). The settling curves of the fine-grained fractions are hyperbolic, with a relative abundance of particles in the coarse silt fraction. Total carbonate content is low $(16 \%-18 \%)$, and the sand fraction is predominantly terrigenous. The $\mathrm{T}_{c}$ division is graded and faintly cross-laminated (Fig. 6).

\section{$T_{d}$ Division}

Sediments of the $\mathrm{T}_{d}$ division are well represented throughout the recovery at Site 637 , although volumetrically they account for only a small proportion of the cored section (Fig. 2 and Table 3). These sediments mostly correspond to clayey silts with a mode at 25-30 $\mu \mathrm{m}$. The grain size curves are positively skewed, with long tails toward the fine-grained fraction and short tails toward the coarse fraction (Fig. 10). The settling curves show a predominant silt fraction between 40 and $10 \mu \mathrm{m}$. Total carbonate content is generally low $(10 \%-20.2 \%)$, and one unit from within the lower Pliocene section (Section 103-637A-17R-1) shows a lower carbonate content $(6 \%-9 \%)$, corresponding to a color change to reddish light brown (Table 2). The sand fraction is significant (normally $4 \%-8 \%$ ) and consists of both terrigenous

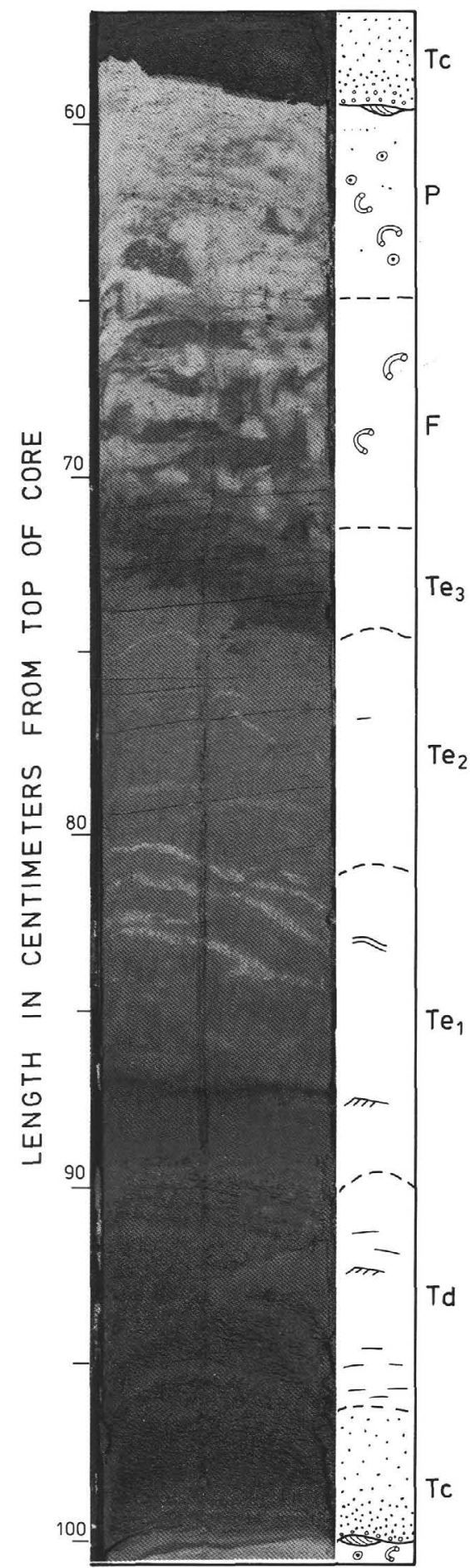

Figure 6. Representative turbidite sequence at Site 637. Sample 103637A-8R-3, 57-100 cm. Lower Pleistocene. Symbols as in Table 1.

and biogenic components. The terrigenous fraction (15\%-95\%) is predominantly mica with subordinate quartz (Pl. 1, Figs. 4$6)$; the biogenic components are dominated by planktonic foraminifers and lesser proportions of benthic foraminifers, although these are significantly more abundant than in the pelagic sediment types. The $T_{d}$ division is parallel laminated, with alternating silt and thinner clay beds, and commonly graded. Synsedimentary deformational structures are common. 


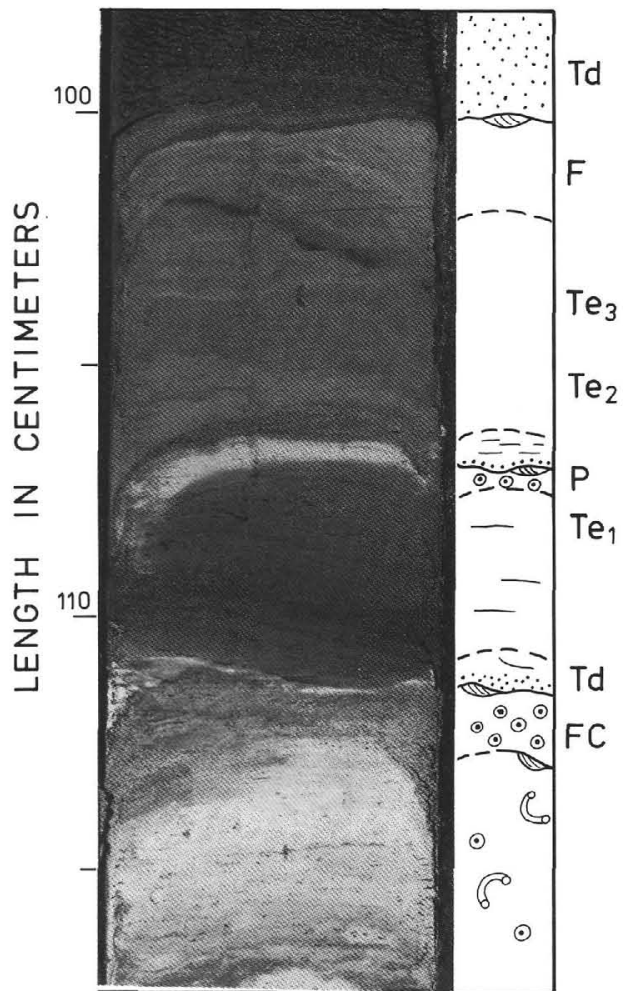

Figure 7. Incomplete base cut out turbidite sequences, pelagites, and foraminiferal sandy contourites. Sample 103-637A-8R-3, 88-117 cm. Lower Pleistocene. Symbols as Table 1.

\section{$T_{e}$.Divisions}

The three $e$ divisions of Piper's (1978) turbidite sequence can be identified on the basis of grain size distribution, sedimentary structures, and position within the sedimentary sequence (Fig. 6). These divisions are gradational, and the limits cannot be precisely established. In total, the three $e$ divisions account for about $85 \%$ of the turbidite facies throughout the stratigraphic section recovered at Site 637 (Table 3). The $T_{e}$ division is graded or faintly laminated at the base and generally bioturbated at the top (Figs. 6-8).

The $\mathrm{T}_{e 1}$ grain size distribution is characterized by very poor sorting with positive skewness and most size fractions finer than $32 \mu \mathrm{m}$ (Fig. 11). A few samples show a poorly marked mode at $16 \mu \mathrm{m}$. The settling curves are hyperbolic, with a straight central segment between 1 and $20 \mu \mathrm{m}$. Total carbonate content is about $20 \%$, and the sand fraction (about $4 \%$ ) has mixed terrigenous and bioclastic components similar those to the $\mathrm{T}_{d}$ division (Table 2, and Pl. 1, Fig. 3). The $\mathrm{T}_{e 1}$ division is graded and laminated with wispy and regular to lenticular silt laminae (Fig. 8).

Deposits characterized by a normal grain size distribution, with a mode centered at $4 \mu \mathrm{m}$, poor sorting, and generally positive skewness are attributed to the $\mathrm{T}_{e 2}$ division. Settling curves of the fine-grained fraction have a similar shape to those of the $\mathrm{T}_{e 1}$ division but are displaced toward the finer fractions (Fig. 11). Sand content and composition are similar to those of the $\mathrm{T}_{e l}$ division. No lamination occurs, but there is a rough normal grading.

The most diagnostic feature of the $T_{e 3}$ division is the shape of the settling curve of the fine-grained fraction. This curve is parabolic and markedly convex upward, whereas the $\mathrm{T}_{e 1}$ and $\mathrm{T}_{e 2}$ curves are concave upward. These sediments have a mode at 2 $\mu \mathrm{m}$ and a tendency to a normal distribution, with balanced tails toward the fine- and coarse-grained fractions (Fig. 11). The deposits are poorly sorted and have a rather symmetrical distribution (skewness close to 0 ). This division corresponds to finegrained deposits of micaceous clay that may have settled from uniform suspension after the main turbidite flow (Pl. 2, Fig. 3). Carbonate content is the lowest of the turbidite sequence $(4.4 \%)$. The sand content is usually zero, although some samples have a very low sand content $(<3 \%)$ as a result of bioturbation from overlying sandy layers. The $\mathrm{T}_{e 3}$ division is ungraded, and bioturbation is common throughout the division or restricted to the top (Figs. 6 and 8).

\section{$F$ Division}

Samples attributed to Piper's (1978) $F$ division, or $\mathrm{T}_{e 8}$ of Stow and Shanmugam (1980), are represented by calcareous clay

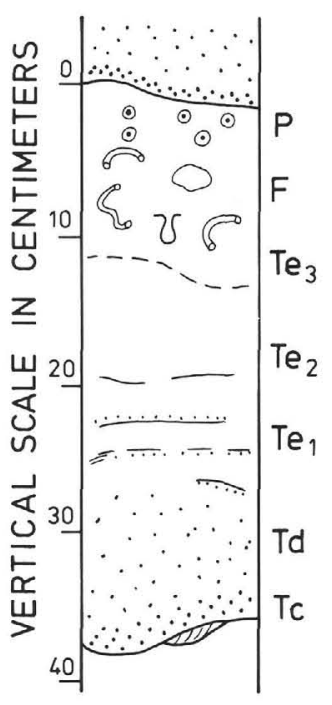

A

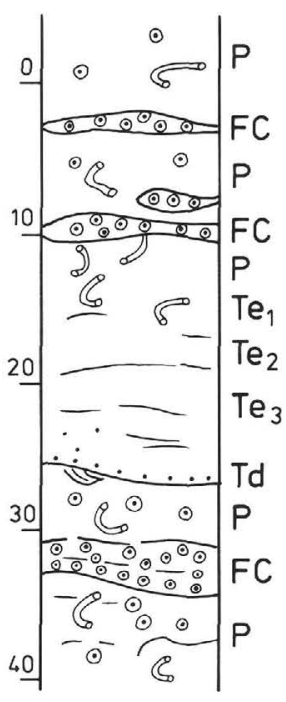

B

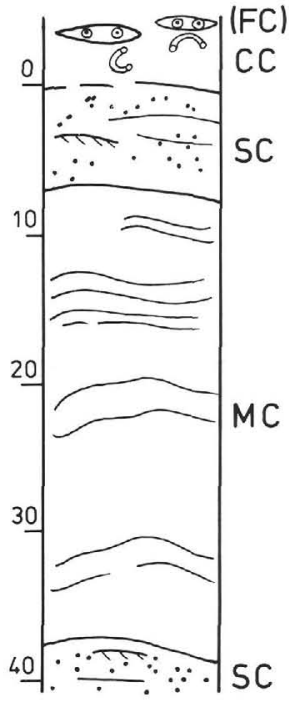

C

Figure 8. Site 637 schematic facies logs. A. Turbidite sequence. B. Pelagic calcareous contouriteturbidite facies association. C. Fine-grained terrigenous-foraminiferal sandy contourite association. Symbols as in Table 1 . 


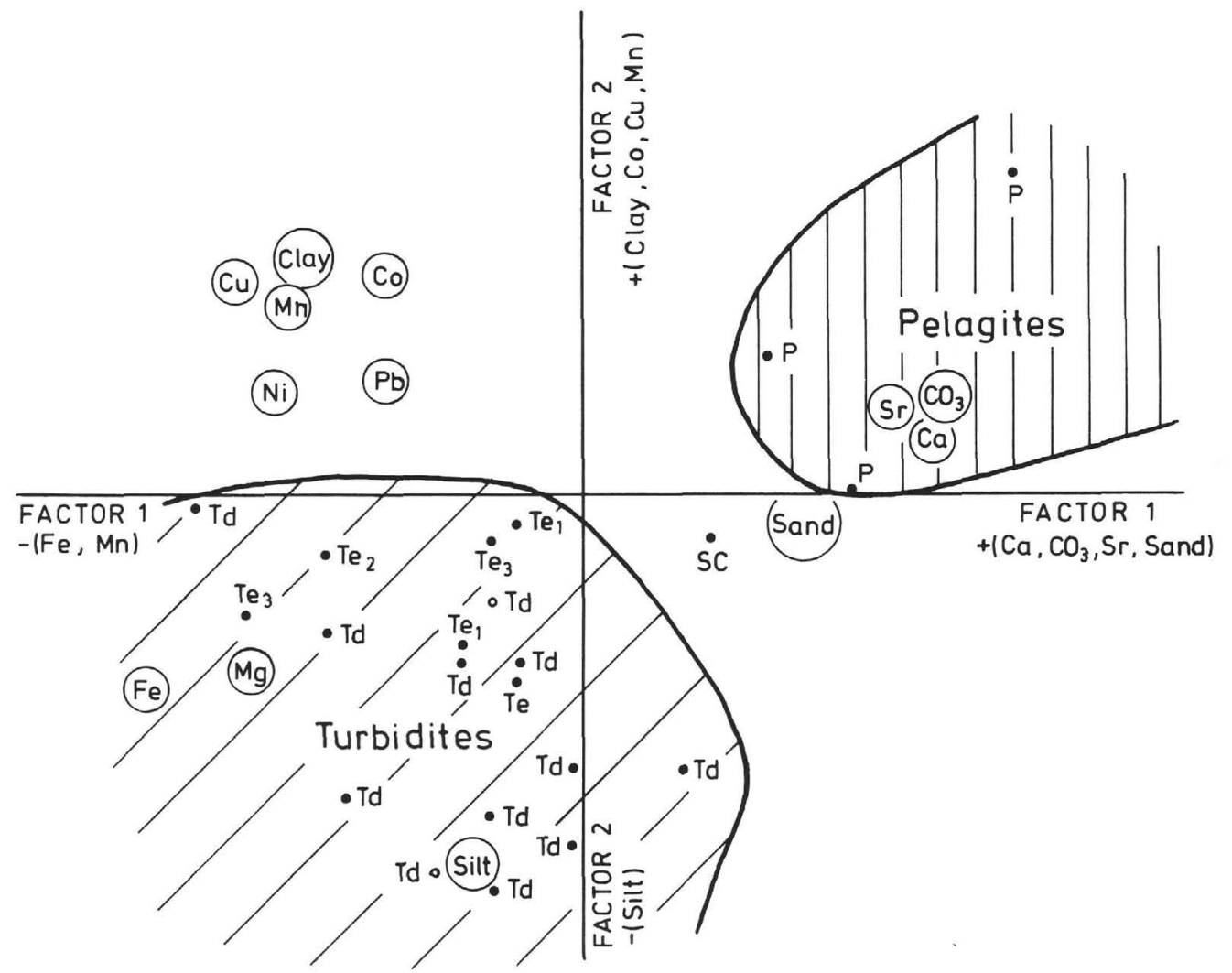

Figure 9. Binary plots defined by the two first factors of the principal component analysis of metal content and grain size parameters (13 variables) of 25 selected samples from Site 637 . The variables are circled in the diagram. Symbols as in Table 1.

Table 3. Percentages of different facies present in the stratigraphic section recovered at Site 637 (Core 103-637A-6R to Section 103-637A-20R-1).

\begin{tabular}{|c|c|c|c|c|c|c|c|}
\hline \multirow[b]{2}{*}{ Core } & \multirow{2}{*}{$\begin{array}{l}\text { Recovery } \\
\text { (m) }\end{array}$} & \multirow{2}{*}{$\begin{array}{c}\text { Pelagites } \\
\text { and } \\
\text { hemipelagites }\end{array}$} & \multicolumn{3}{|c|}{ Turbidites } & \multirow[b]{2}{*}{ Contourites } & \multirow[b]{2}{*}{ Slump } \\
\hline & & & Total & $\mathrm{T}_{d}\left({ }_{c}\right)$ & $\mathrm{T}_{e}$ & & \\
\hline $6 \mathrm{R}$ & 4.6 & 40 & 60 & 10 & 90 & - & - \\
\hline $7 \mathrm{R}$ & 5.5 & 12 & 53 & 39 & 61 & 18 & - \\
\hline $8 \mathrm{R}$ & 4.3 & 34 & 65 & 16 & 84 & 1 & - \\
\hline $9 \mathrm{R}$ & 2.8 & 16 & 84 & 14 & 86 & - & - \\
\hline $10 R$ & 1.8 & 34 & 67 & 2 & 98 & - & - \\
\hline $11 R$ & 1.6 & 6 & 80 & 4 & 96 & 4 & - \\
\hline $12 \mathrm{R}$ & 2.9 & 20 & 78 & 6 & 94 & 2 & - \\
\hline $13 R$ & 2.5 & 13 & 87 & 15 & 85 & - & - \\
\hline $14 R$ & 1.7 & 9 & 91 & 6 & 94 & - & - \\
\hline $15 \mathrm{R}$ & 5.5 & 38 & 62 & 40 & 60 & - & $*$ \\
\hline $16 R$ & 4.8 & 43 & 57 & 3 & 97 & - & $*$ \\
\hline $17 \mathrm{R}$ & 5.2 & 42 & 55 & $\begin{array}{r}35 \\
2\end{array}$ & $\begin{array}{l}65 \\
98\end{array}$ & 3 & - \\
\hline $18 \mathrm{R}$ & 2.8 & - & - & - & - & 100 & - \\
\hline $19 R$ & 3.5 & 10 & $\operatorname{tr}$ & - & - & 90 & $*$ \\
\hline $20 R$ & 1.3 & - & - & - & - & 100 & - \\
\hline
\end{tabular}

Note: $\operatorname{tr}=$ trace; ${ }^{*}=$ occurrence of slumps.

and marl (Table 1). Observed on top of the turbidite layers, this division is bioturbated and locally very reduced or mixed with overlying pelagic calcareous deposits (Figs. 6 and 8). The grain size distribution is very poorly sorted, with an poorly defined mode between 2 and $4 \mu \mathrm{m}$ and long tails toward the coarse and fine-grained fractions. Most fractions are finer than $16 \mu \mathrm{m}$. The settling curves of the fine fraction have a parabolic tendency (Fig. 11). Total carbonate content is high, normally $20 \%-40 \%$, but a few samples exceed this range. The sand fraction is always present, but low $(<2 \%)$ and largely biogenic ( $>90 \%$ foraminifers) (Table 2 and Pl. 2, Fig. 2). The $F$ division corresponds to clayey hemipelagic sediments, with moderate to well-preserved nannoplankton (Pl. 2, Fig. 2).

\section{Contourites}

The two main facies associations within sediments attributed to contourites at Site 637 are (1) a calcareous-rich association, formed by foraminiferal sands, and (2) a mixed calcareous-terrigenous association with a low carbonate content and composed of clayey silt, silty clay, or clay (Table 1 and Fig. 3).

\section{Foraminiferal Sandy Contourites}

A few beds in Sections 103-637A-7R-1 to 203-637A-20R-1 are composed of foraminiferal sands $(27 \%-53 \%)$, with subordinate amounts of carbonate silts $(27 \%-39 \%)$ and clays $(22 \%-39 \%)$ (Table 2). These sandy sediments are either reverse graded, normal graded, or structureless and are commonly bioturbated. They form thin irregular layers (normally $<15 \mathrm{~cm}$ ) and, in some cores, are associated to thicker nannofossil ooze beds (Sections 103-637A-7R-2, 103-637A-8R-2, and 103-637A-17R-2). In other instances, the foraminiferal beds show sharp basal and top contacts (Figs. 8, 12, and 13).

The grain size distribution is polymodal, with a principal mode at $125 \mu \mathrm{m}$ and subordinate modes in the silt and clay fractions. The settling curve of the fine-grained fraction is almost straight, with some minor inflections (Fig. 14). The skewness is positive and the sorting very poor. Total carbonate content is high $(55 \%-75 \%)$. The sand fraction is composed of fragmented planktonic and benthic foraminifers $(>80 \%)$, with some glauconized tests (Pl. 3, Fig. 1).

Our attribution of the foraminiferal sand to contourites is based on the following characteristics: (1) absence of well-defined vertical sequences, (2) sedimentary structures with both 

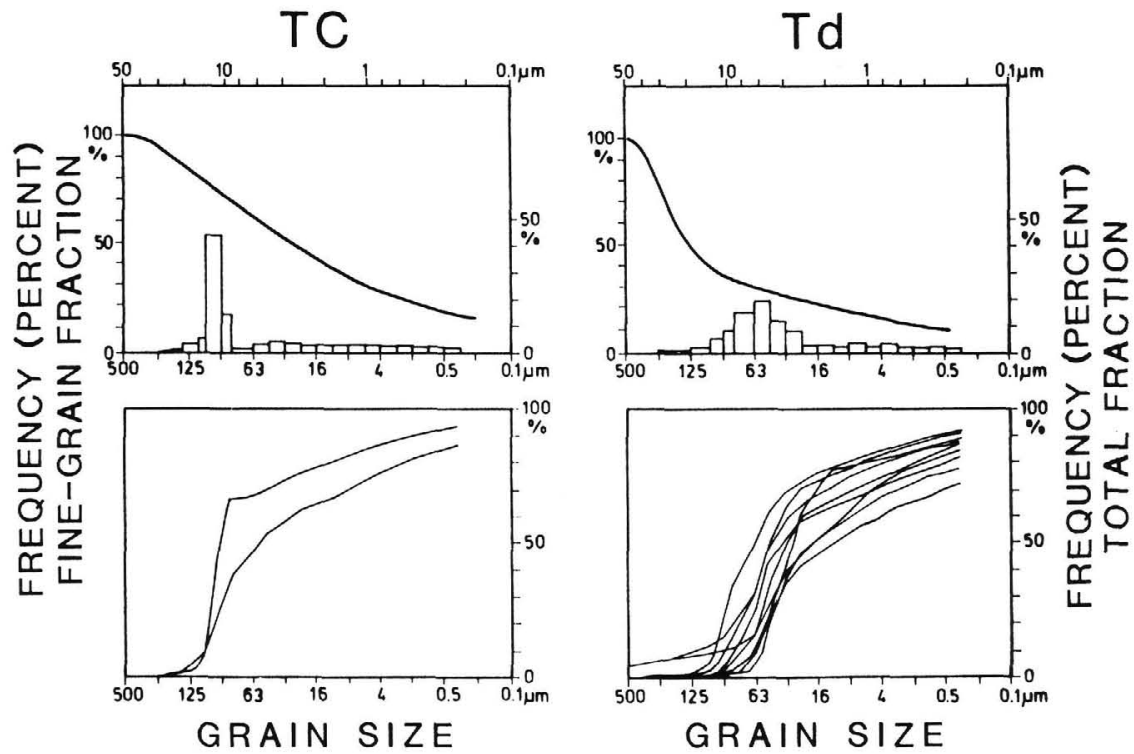

Figure 10. Cumulative curves and frequency histograms of the $\mathrm{T}_{c}$ and $\mathrm{T}_{d}$ divisions of silt turbidites. A distribution histogram of the total grain size distribution and a Sedigraph cumulative curve of the fine-grained $(<50 \mu \mathrm{m})$ size fraction are shown for one representative sample from each division. The lower diagram of each division pair corresponds to the cumulative curve of the total grain size distribution of all the samples analyzed in the division.

negative and positive grading, (3) bioturbation throughout the bed, (4) compositional features that indicate mixture of autochthonous or allochthonous components and reworking (broken fossils predominate), and (5) the polymodal grain size distribution.

The foraminiferal sands commonly occur within pelagic units as discrete beds or lenses, without a vertical transition. These beds are usually structureless, although some grading is observed. Graded beds, however, usually have reverse, rather than normal, grading and exhibit sharp upper contacts with overlying mud. In other instances, the foraminiferal sands are at the base or interbedded with foraminifer-rich clayey oozes. These clayey oozes attributed to calcareous mud contourites contain irregular lenses and layers of foraminiferal sands. In this case, the contacts between oozes and foraminiferal sands are gradational.

The polymodal grain size distribution of foraminiferal sands and the low percentage of the coarse silt fraction contrast with the classical sand-silt turbidites at Site 637, which are characterized by an unimodal distribution pattern and the relative abundance of silt fractions.

Evidence for bottom-current activity during the deposition of the foraminiferal sands is illustrated by the sharp erosional basal contact and the lenticular flaserlike nature of some of these deposits (Fig. 8B). On the other hand, the normally graded structures of the foraminiferal sand at Site 637 could be attributed to deposition from a turbidity flow (Shipboard Scientific Party, 1987). In this case, these turbidity flows would have originated from slumps of pelagic deposits on the continental slope. However, calcareous turbidites described from distal deep-sea environments generally display standard turbidite sequences, which are not present in the Site 637 foraminiferal sand beds. For example, at the northern Mid-Atlantic Ridge (Gonthier et al., 1981; Faugères et al., 1979), the carbonate turbidites always have a basal, normally graded calcareous sand division, followed by laminated silty-sandy mud and homogenous clayey muds, as illustrated in other deep-sea cores (Kelts and Arthur, 1981).
The foraminiferal sands are similar to other classic sandy contourite deposits (Stow and Holbrook, 1984), although there are some differences. The Faro Drift contourites, for example, show bedding features and vertical successions (Stow, 1982; Faugères et al., 1984) that are similar to the foraminiferal sand and associated calcareous deposits at Site 637. However, the grain size distribution and composition of the sand fraction is less terrigenous and more positively skewed at Site 637 . These differences may be attributed to the contrast in oceanographic setting between the Iberian Abyssal Plain and the Gulf of Cadiz continental slope and to the type of bottom currents that were active in each environment.

We consider the Site 637 foraminiferal sand to be largely a type of lag deposit, developed by winnowing of the fine-grained carbonate fraction by bottom currents. The sedimentary source may be in-situ fine-grained pelagic facies, although there is distal source contribution from flows of diverse density originating on the rise, as demonstrated by the association of benthic foraminifers.

\section{Silt Contourites}

The lowermost Pliocene and upper Miocene section at Site 637 (Cores 103-637A-18R to 103-637A-20R) includes beds of multicolored brownish, rhythmically bedded and laminated, mottled silty and clay deposits attributed to contourites (Table 1 and Fig. 3). The silty beds form thin irregular laminae and lenses in the muds. The basal and top contacts are characteristically sharp; there is some evidence of scouring at the base. These sediments have a bimodal or polymodal grain size distribution, with a mode in the coarse silt fraction $(20-40 \mu \mathrm{m})$ and a secondary mode in the clay fraction $(0.5-2 \mu \mathrm{m})$. The skewness is close to zero, and the sorting is very poor. The settling curve of the finegrained fraction is commonly bimodal, with a large proportion in the coarse silt and coarse clay fractions and a small proportion in the fine silt fraction (Table 2 and Fig. 14). Total carbonate content is low $(12 \%-20 \%)$, and the sand fraction is abundant $(6 \%-13 \%)$. The components of the sand fraction are predominantly terrigenous $(85 \%-90 \%)$, and the foraminifers are 

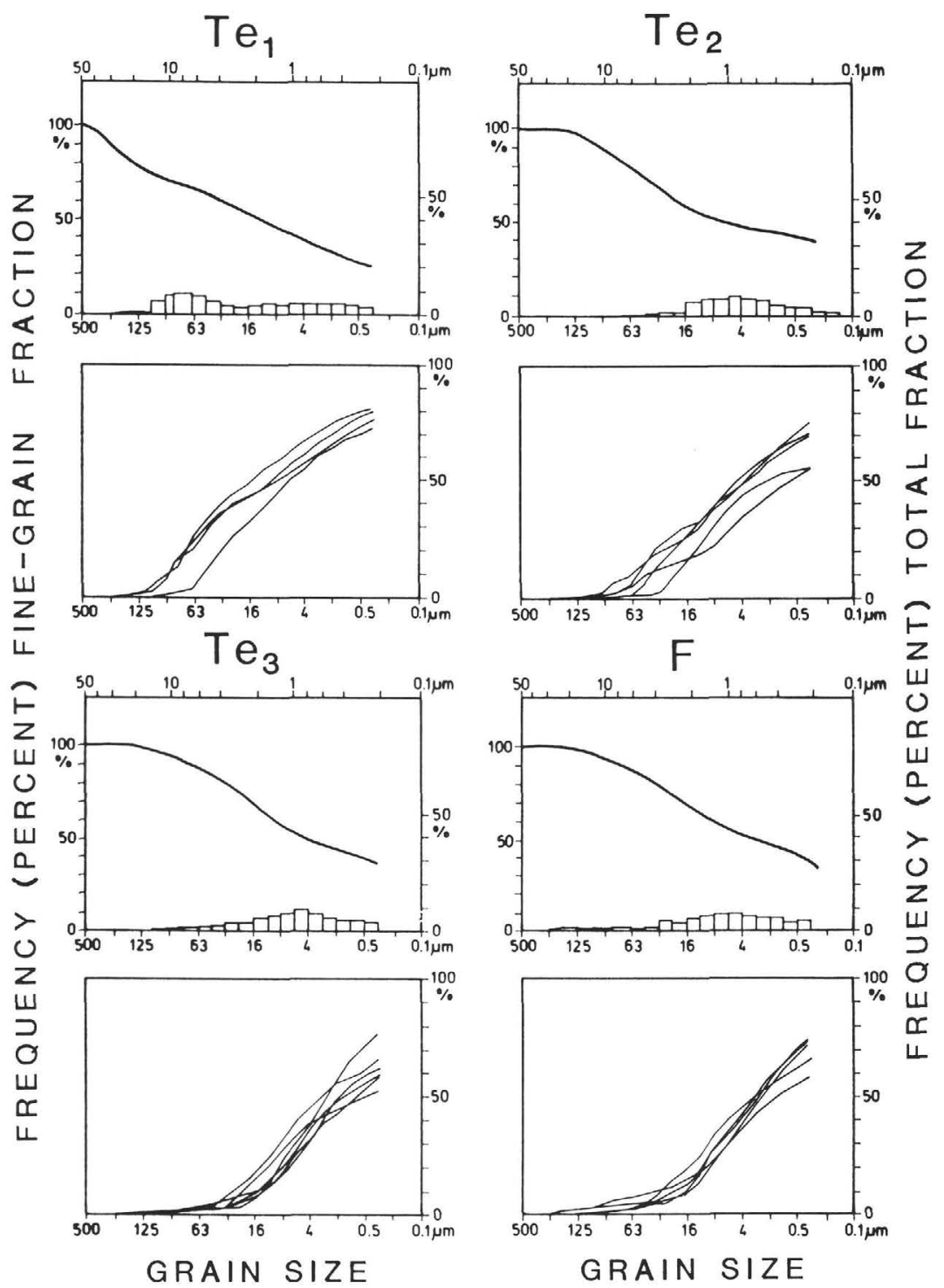

Figure 11. Cumulative curves and frequency histograms of the fine-grained $T_{e 1}, T_{e 2}, T_{e 3}$, and $\mathrm{F}$ divisions of the turbidite sequence. A distribution histogram of the total grain size distribution and a Sedigraph cumulative curve of the fine-grained $(<50 \mu \mathrm{m})$ size fraction are shown for one representative sample from each division. The lower diagram of each division pair corresponds to the cumulative curve of the total grain size distribution of all the samples analyzed in the division.

poorly preserved (Pl. 3, Figs. 2 and 5). Moderate to poorly preserved nannoplankton are present (Pl. 2, Fig. 4).

The diagnostic features that significantly differentiate these deposits from the $T_{d}$ division turbidites are (1) the absence of well-defined vertical sequences, similar to the foraminiferal sands; (2) the bimodal grain size distribution in both the total cumulative curve and the settling curve of the fine-grained fraction; (3) the low proportions of some grain size fractions, such as fine silt, and the relative abundance of the fine clay fraction; and (4) the tendency toward negative skewness.

\section{Mud Contourites}

Deposits attributed to mud contourites are well represented in Cores 103-637A-18R through 103-637A-20R (Fig. 2). These deposits are laminated, with wavy or wispy laminations well illustrated by color changes. The layers are thin $(<2 \mathrm{~cm})$ and form sequences several decimeters thick of alternating layers
(Figs. 12 and 13). Total carbonate content is low (8\%-16\%); the predominant grain size fraction is clay $(>54 \%)$, and the sand content is low $(0.7 \%-5 \%)$ (Table 2 and Fig. 7).

The grain size distribution is normally bimodal, with a predominant mode in the clay fraction $(1-2 \mu \mathrm{m})$ and an ill-defined secondary mode in the silt fraction (16-32 $\mu \mathrm{m})$. The settling curve of the fine-grained fraction shows an abundance of grain sizes between 1 and $5 \mu \mathrm{m}$ and large proportions $(>40 \%)$ of particles finer than $0.2 \mu \mathrm{m}$ (Fig. 14). The sand fraction is largely terrigenous $(>92 \%)$ with a mixed population of poorly preserved benthic/planktonic foraminifers and fish teeth (Pl. 3, Fig. 3). Nannoplankton are poorly preserved (Pl. 2, Fig. 5).

Biogenic calcareous ooze is another variety of mud contourites that is normally associated with the foraminiferal sands (Cores 103-637A-7R, 103-637A-8R, 103-637A-17R, and 103-637A-20R). The most significant difference with the terrigenous mud contourites is the total carbonate content. 


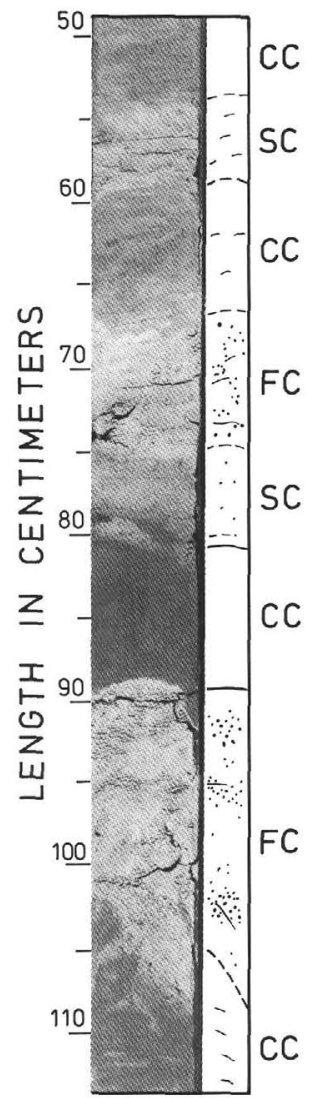

Figure 12. Characteristic contourite association of foraminiferal sand, clay, and silt. Sample 103-637A-18R-1, 50-114 cm. Lowermost Pliocene. Symbols as in Table 1 .

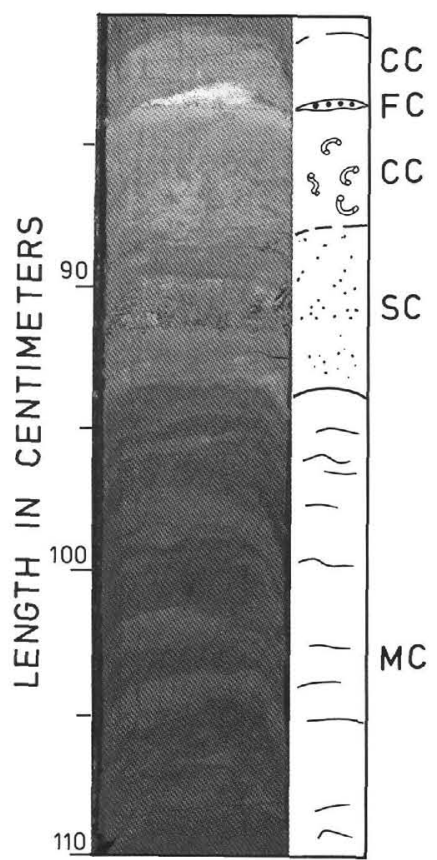

Figure 13. Typical facies association of terrigenous (silt, mud, and clay) and foraminiferal sandy contourites. Sample 103-637A-18R-2, 81-110 $\mathrm{cm}$. Upper Miocene. Symbols as in Table 1.
The deposits attributed to contourites differ from fine-grained turbidites in bedding features, lack of vertical transition, and grain size distribution. The bottom currents responsible for the development of these contourites could be the type that transport very low concentrations of suspended matter in bottom nepheloid layers. These weak currents were not competent enough to produce significant erosion or sediment resuspension, as evidenced by the lack of scouring in the sequences. However, the wavy nature of the bedding demonstrates variations in the flow characteristics that may be attributed to seasonal and irregular periodicities in the velocity and direction field of flow.

\section{Clay Contourites}

The finest grained sediments attributed to deposition from bottom nepheloid layers are the clay contourites. These are deposits of predominantly clay-sized material $(84 \%-90 \%)$ with minor proportions of silt $(9 \%-15 \%)$ and sand $(0.3 \%-1.4 \%)$ fractions (Table 2 and Fig. 3). These deposits alternate with the other contourite types, without a definite vertical sequence. The upper and lower contacts of the clay contourites may be sharp, usually in contact with the foraminiferal sands, but in some instances, the contacts are gradational or obscured by burrowing. These deposits are massive and irregularly bioturbated, varying from extensive bioturbation to mottled to isolated burrows (Figs. 12 and 13).

The grain size distribution is unimodal (mode at 1-2 $\mu \mathrm{m}$ ) with long tails toward the fine- and coarse-grained fractions (Fig. 14). Sorting is poor and skewness is toward negative values. Total carbonate content is low (Table 2). The sand fraction is small and is predominantly biogenic, composed mostly of poorly preserved fragments of planktonic and benthic foraminifers and fish teeth (Pl. 3, Fig. 6). Preservation of the nannoplankton is very poor (Pl. 2, Fig. 6).

The attribution of these deposits to contourites is not unequivocal. The very fine texture of the deposits and the lack of sedimentary structures indicative of strong bottom currents impose some constrictions in the type of depositional processes. The bottom currents responsible for the development of these deposits were weak and only slightly affected the suspended sediment entering the bottom nepheloid layer. These currents must have produced a preferential settling of particles in the 0.5-4$\mu \mathrm{m}$ range. The depositional processes could have been intermediate between bottom currents and pelagic differential settling. The lack of a significant biogenic sand fraction, extensive vertical mixing by bioturbation, and the preferential settling of grain size fractions indicate, however, differences in comparison to other pelagic deposits at Site 637.

\section{DISCUSSION AND STRATIGRAPHIC EVOLUTION}

\section{Facies Evolution}

The general distribution of facies types throughout the upper Cenozoic section is shown in Figure 2 and quantified in Table 3. Calcareous biogenic sediments attributed to differential pelagic settling account for about $25 \%$ of the entire stratigraphic section. A general increase is noted in the carbonate pelagic contribution in the Pleistocene, forming $30 \%$ of lower Pleistocene Subunit IB (Cores 103-637A-6R to 103-637A-9R) but about only $20 \%$ of Subunit IC (Cores 103-637A-10R and 103-637A-11R). In the Pliocene section, the maximum abundance of pelagic beds $(41 \%)$ occurs at the boundary between the lower and upper Pliocene (Cores 103-637A-15R to 103-637A-17R). This carbonate-rich section is between two carbonate-poor facies $(1 \%$ $14 \%$ carbonate), suggesting a cyclicity to the carbonate contribution during the Pliocene. The slumps of the upper Miocene section include beds of biogenic pelagites. 

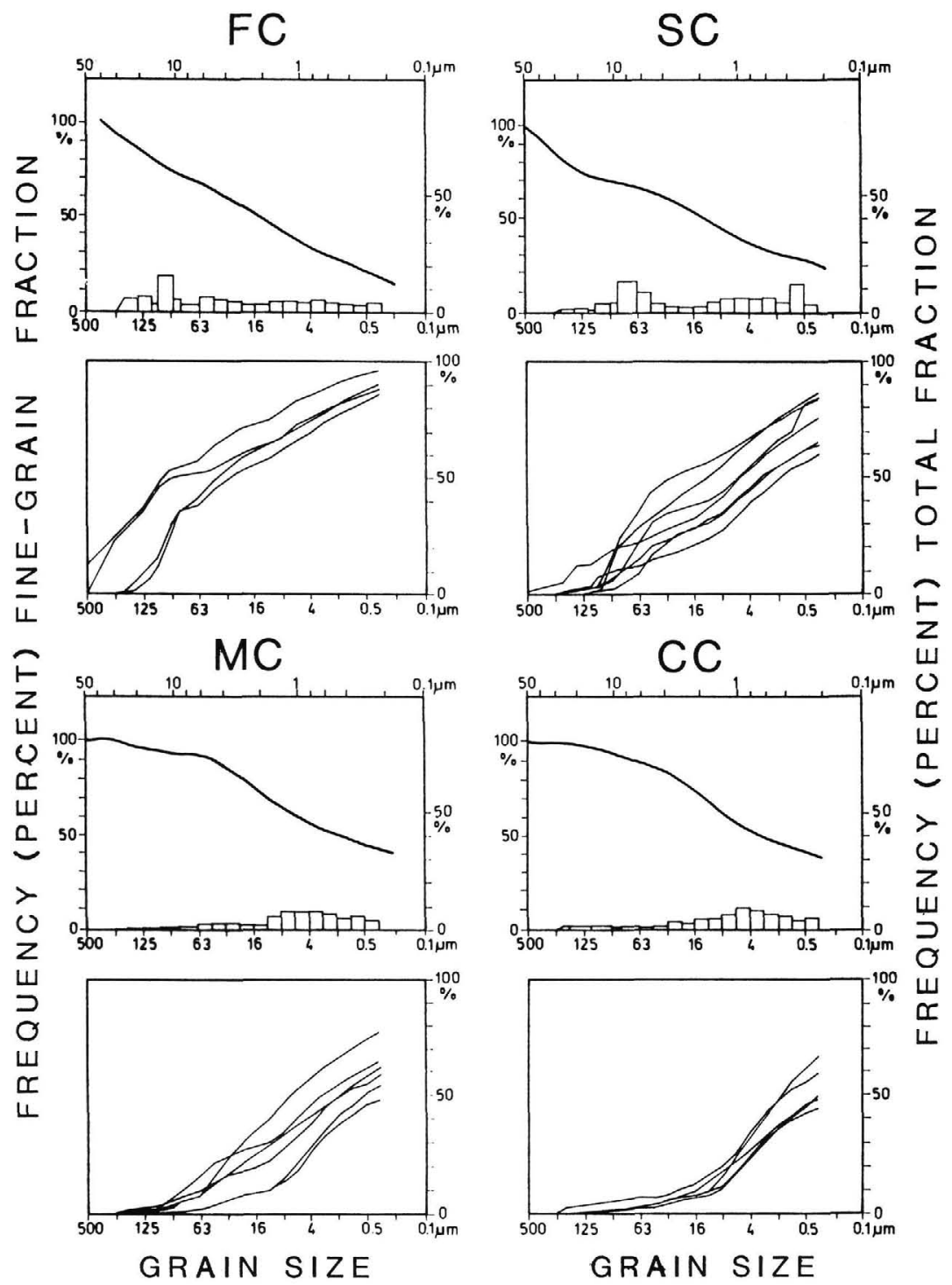

Figure 14. Cumulative curves and frequency histograms of calcareous and terrigenous contourite facies. A distribution histogram of the total grain size distribution and a Sedigraph cumulative curve of the fine-grained $(<50 \mu \mathrm{m})$ size fraction are shown for one representative sample from each facies. The lower diagram of each division pair corresponds to the cumulative curve of the total grain size distribution of all the samples analyzed in the facies. Symbols as in Table 1.

Turbidites are the dominant facies through the Pliocene-Pleistocene section, comprising about $69 \%$ of the total stratigraphic thickness. In the upper lower Pleistocene (Subunit IB; Cores 103-637A-6R to 103-637A-9R) the turbiditic sequences are thicker (from 15 to $40 \mathrm{~cm}$ ) and normally include $\mathrm{T}_{d}$ divisions at the base. The lowermost Pleistocene and uppermost Pliocene (Subunit IC; Cores 103-637A-10R to 103-637A-14R) sequences are generally thinner (from 5 to $15 \mathrm{~cm}$ ), and the $\mathrm{T}_{d}$ division is highly reduced. Within this time interval, the facies distribution shows a poorly developed pattern of thickening and coarsening-upward sequences.

In the lower upper Pliocene, thick $(15-30 \mathrm{~cm})$ silty turbidite sequences reappear (Sections 103-637A-15R-1 and 103-637A15R-2), overlying a thick interval of slumps. The lowermost silty turbidite interval occurs in the lower Pliocene in Section 103637A-17R-1, disappearing by the lowermost Pliocene Section 103-637A-17R, CC. According the biostratigraphic age determi- nation (see "Biostratigraphy" section of the "Site 637" chapter; Shipboard Scientific Party, 1987) and the abundance of turbiditic rhythms, we have estimated the frequency of turbidity current events to be one turbidite event every $3.4 \times 10^{3} \mathrm{yr}$ for the Pleistocene and approximately one turbidite event every $4.4 \times$ $10^{3} \mathrm{yr}$ for the Pliocene.

The contourite facies show a distinct distribution in the upper Cenozoic section. Carbonate contourites, although scarce $(<10 \%)$, are widespread and dispersed throughout the lower Pleistocene to upper Miocene section. In turn, muddy terrigenous contourites are restricted to the lowermost Pliocene and upper Miocene (from Sections 103-637A-17R-3 to 103-637A20R-1), where they constitute up to $90 \%$ of the stratigraphic section (Fig. 2). Mass gravity flow facies occur as slumps in the middle Pliocene and upper Miocene. The facies involved in the slumps have characteristics similar to the other facies of the stratigraphic section. 
The sedimentation rate shows a close correlation with the facies distribution (Fig. 2). The rate calculated for the facies association of turbidites, pelagites, and subordinate contourites of the lower Pleistocene is about $63 \mathrm{~mm} / 1000$ yr. For the similar upper Pliocene facies association, the sedimentation rate is lower, ranging from 21 to $26 \mathrm{~mm} / 1000$ yr. During the late early Pliocene the sedimentation rate increased, with values for the turbidite-rich interval of Cores 103-637A-16R and 103-637A-17R of about $59 \mathrm{~mm} / 1000 \mathrm{yr}$. From the late Miocene to the earliest Pliocene, when dominantly contourite facies were deposited, the sedimentation rate was lower, approximately $8 \mathrm{~mm} / 1000 \mathrm{yr}$. Taking the bulk density of sediment into consideration, the preceding values correspond to $11.3,4.6$ to $3.9,11.2$, and $1.5 \mathrm{~g} /$ $\mathrm{cm}^{2} / 1000$ yr (Fig. 2, in brackets). Because of the uncertainty in the radiometric age of some biozones, the poor recovery, and interbedded slump intervals, these values should be considered only as approximations. Nevertheless, the order of magnitude is probably valid (Shipboard Scientific Party, 1987).

\section{Oceanographic Control and Summary}

The sedimentologic analysis of sediments recovered at Site 637 reveals a complex pattern of late Cenozoic sedimentation on the Iberian Abyssal Plain near Hill 5100. In addition to pelagic settling, sedimentation was controlled by both downslope mass gravity processes and bottom currents.

Turbidity currents and pelagic/hemipelagic settling were the significant deposition processes during the Pliocene and Pleistocene. Bottom currents predominated during the late Miocene. Slump events, probably related to tectonic pulses or oversteepening of the margin, occurred from the early to late Pliocene. The upper Cenozoic sediments recovered at Site 637 show a general upward transition from contourites to turbidites. Nevertheless, during some Pleistocene intervals both contourites and turbidites were deposited (Fig. 2).

The turbidite facies records the terrigenous input to the distal continental margin. The siliciclastic materials were probably contributed by low-density turbidity flows from the outer shelf or slope of the Iberian margin, via the submarine valleys or the morphologically complex Galicia margin (Fig. 1). The turbidite sequences are classical thin-bedded, fine-grained (muddy), distal basin plain facies. Significant sand and coarse silt sediment are absent and may have been trapped on the more proximal depositional environments of the margin or behind the tilted blocks and seamounts.

Total organic carbon content of the Pliocene-Pleistocene turbidite section ranges from $0.2 \%$ to $0.8 \%$. Organic carbon content shows an oscillatory trend within the Pliocene and Pleistocene, with a minimum $(<0.2 \%)$ in the lowermost Pliocene and upper Miocene, where the input of turbidity flows decreases and reddish colorations appear (see "Organic Geochemistry" section of the "Site 637" chapter; Shipboard Scientific Party, 1987). Organic-rich, dark gray to gray Pliocene-Pleistocene turbidites suggest local reducing conditions within the sediments, leading to the production of hydrogen sulfides and the deposition of pyrite minerals. These sediments may be relatively enriched in $\mathrm{Fe}$ and $\mathrm{Mn}$, with lesser amounts of other heavy metals, such as $\mathrm{Ni}, \mathrm{Pb}$, and $\mathrm{Co}$ (Fig. 9). Alternation of reddish and gray sediments in the middle upper Pliocene section (i.e., Core 103637A-15R) probably resulted from fluctuations in the redox conditions at Site 637. Changes in redox conditions within the sediments may represent variable rates of supply of the organic detritus brought by turbidity currents.

The cyclic depositional patterns attributed to climatic oscillation in the Pliocene-Pleistocene section of the North Atlantic are well documented (Davis and Laughton, 1972; Chamley and Diester-Haass, 1979; Cita and Ryan, 1979; Diester-Haass, 1979; Stow, 1979; Stow and Holbrook, 1984; Emery and Uchupi,
1984). As sea level rose during the early Pliocene (from 5.3 to $3.2 \mathrm{Ma}$ ), a decrease in carbonate dissolution occurred in coincidence with a global lowering of the CCD at about 4.5 Ma. This evolution is well documented on the northwestern African margin (Sarnthein et al., 1982). More recently, from the late Pliocene to the Pleistocene, changes in the depositional pattern in the North Atlantic have been well correlated with eustatic-climatic oscillations and the rhythms attributed to the orbital control in the Earth's insolation produced by Milankovitch-type cycles. The orbital variations may have controlled the onset of glaciation-deglaciation periods in the northwestern hemisphere. These drastic climatic changes produced variations in sea level, deep and surface water circulation, productivity in surface waters, and upwelling phenomena (Cita and Ryan, 1979; Chamley and Diester-Haass, 1979; Sarnthein et al., 1982). The oscillatory trend in the siliciclastic input recorded by the Pliocene-Pleistocene turbidite deposits at Site 637 can be related to these events. The Pliocene to Pleistocene ratio of hemipelagic to turbidity current sedimentation is about $3 / 8$. This relatively high ratio suggests sedimentation influenced primarily by eustatic/climatic oscillations and secondarily by tectonic factors.

Late Miocene bottom-current activity is documented in the North Atlantic by the low pelagic sedimentation rate and extensive hiatuses (Davis and Laughton, 1972; Sarnthein et al., 1982; Emery and Uchupi, 1984). At Site 637, contour-current activity was important during the late Miocene also. Slow sedimentation rates (about $8 \mathrm{~mm} / 1000 \mathrm{yr}$ ) are probably due to postdepositional erosion or nondeposition. Moreover, the hiatuses detected at Site 637 at the top of the Miocene section and the minor gaps in the lower Pliocene could be related to the bottom-current activity. The strong similarity between the upper Miocene brown clayey contourites and underlying Paleogene brown clays suggests that contour currents may have eroded the nearby seamounts and provided materials from resuspension of older brown clay deposits (Shipboard Scientific Party, 1987).

Another important factor that may have controlled sedimentation during the late Cenozoic at Site 637 is carbonate dissolution. In the North Atlantic, temporal variations of the CCD respond to changes in the nature and circulation of deep water (van Andel et al., 1977). Carbonate pelagic facies occur in the Pleistocene and most of the Pliocene part of the stratigraphic succession off the Galicia margin at Site 637, whereas in the upper Miocene deposits, the autochthonous carbonates are scarce and poorly preserved, suggesting deposition close to the CCD. Considering that the present oceanographic conditions were well established by latest Miocene (Keller and Barron, 1983), the observations at Site 637 suggest that the CCD was close to $5450 \mathrm{~m}$ in the late Miocene and that during the Pliocene-Quaternary, the CCD remained below the water depth of Site 637; that is, below $5450 \mathrm{~m}$ in the late Pliocene and below $5300 \mathrm{~m}$ in the late Quaternary. This evolution of the CCD at Site 637 may represent the global lowering of the CCD at about $4.5 \mathrm{Ma}$.

\section{ACKNOWLEDGMENTS}

M. C. Comas thanks Ocean Drilling Program for inviting her to participate on Leg 103. We thank A. W. Meyer, G. Boillot, H. Nelson, and P.P.E. Weaver for corrections and comments. We also thank A. Palanques for the chemical analysis, E. Vergés for laboratory help, and $\mathbf{M}$. Solans for technical assistance. Financial support was provided by the Spanish Committee for the ODP and Council for Scientific Research (C.S.I.C., Spain).

\section{REFERENCES}

Agemian, M., and Chan, A.S.Y., 1976. Evaluation of extraction techniques for the determination of metals in aquatic sediments. Analysis, 101:761-767.

Berger, W. H., 1974. Deep sea sedimentation. In Burk, C. A., and Drake, C. L. (Eds.), The Geology of the Continental Margins: Berlin (Springer-Verlag), 213-241. 
Boillot, G., Auxiètre, J. L., Dunand, J. P., Dupeuble, P. A., and Mauffret, A., 1979. The northwestern Iberian margin: a Cretaceous passive margin deformed during Eocene. In Talwani, M., Hay, W., Ryan, W.B.F (Eds.), Deep Drilling Results in the Atlantic Ocean. Continental Margins and Paleoenvironment: Am. Geophys. Union, Maurice Ewing, Ser. 3: 139-153.

Boillot, G., Grimaud, S., Mauffret, A., Mougenot, D., Mergoil-Daniel, J., Kornprobst, J., and Torrent, E., 1980. Ocean-continent boundary off the Iberian margin: a serpentinite diapir west of the Galicia Bank. Earth Planet. Sci. Lett., 48:23-34.

Boillot, G., Winterer, E. L., et al., 1987. Proc. ODP, Init. Repts., 103: College Station, TX (Ocean Drilling Program).

Carmody, D. J., Pearce, J. B., and Yasso, W. E., 1973. Trace metals in sediments of New York Bight. Mar. Pollut. Bull., 4:132-135.

Cita, M. B., and Ryan, W.B.F., 1979. Late Neogene environmental evolution. In von Rad, U., Ryan, W.B.F., et al., Init. Repts. DSDP, 47 Pt. 1: Washington (U.S. Govt. Printing Office), 447-459.

Chamley, H., and Diester-Haass, L., 1979. Upper Miocene to Pleistocene climates in northwest Africa deduced from terrigenous components of Site 397 sediment (DSDP Leg 47A). In von Rad, U., Ryan, W.B.F., et al., Init. Repts. DSDP, 47, Pt. 1: Washington (U.S. Govt. Printing Office), 641-646.

Davis, T. A., and Laughton, A. S., 1972. Sedimentary processes in North Atlantic. In Laughton, A. S., Berggren, W. A., et al., Init. Repts. DSDP, 12: Washington (U.S. Govt. Printing Office), 905 934.

Diester-Haass, L., 1979. DSDP Site 397: climatological, sedimentological, and oceanographic changes in the Neogene autochthonous sequence. In von Rad, U., Ryan, W.B.F. et al., Init. Repts. DSDP, 47, Pt. 1: Washington (U.S. Govt. Printing Office), 647-670.

Emery, K. O., and Uchupi, E., 1984. The Geology of the Atlantic Ocean: New York (Springer-Verlag).

Faugères, J. C., Gayet, J., Gonthier, E., Grousset, F., Latouche, C., Maillet, N., Poutiers, J., and Tastet, J. P., 1979. Evolution de la sédimentation profonde au Quaternaire récent dans le bassin nord-atlantique: corps sédimentaires et sédimentation ubiquiste. Bull. Soc. Geol. Fr, 7:585-601.

Faugères, J. C., Stow, D.A.V., and Gonthier, E., 1984. Contourite drift moulded by deep Mediterranean outflow. Geology, 12:231-233.

Giró, S., and Maldonado, A., 1985. Análisis granulométrico por métodos automáticos: tubo de sedimentació y Sedigraph. Acta Geol. Hisp., 20:95-102.

Gonthier, E., Faugères, J. C., and Weber, O., 1981. Signification des méthodes granulométriques pour la reconstitution des processus hydrodynamiques á partir de sédiments terrigènes carbonatés de milieux marins profonds. Bull. Inst. Geol. Bassin Aquitaine, 30:31-49.

Gorsline, D. S., 1984. A review of fine-grained sediments origins, characteristics, transport and deposition. In Stow, D.A.V., and Piper, D.J.W. (Eds.), Fine-Grained Sediments: Deep-Water Processes and Facies: London (Blackwell), 17-34.

Keller, E., and Barron, J. A., 1983. Paleogeographic implications of Miocene deep-sea hiatuses. Geol. Soc. Am. Bull., 94:590-613.

Kelts, K., and Arthur, M. A., 1981. Turbidites after ten years of deepsea drilling-wringing out the mop? In Warme, J. E., Douglas, R. G., and Winterer, E. L. (Eds.), The Deep Sea Drilling Project: A Decade of Progress: Spec. Publ. Soc. Econ. Paleontol. Mineral., 32: 91-127.

Kranck, K., 1984. Grain-size characteristic of turbidites. In Stow, D.A.V., and Piper, D.J.W. (Eds.), Fine-Grained Sediments: Deep-Water Processes and Facies: London (Blackwell), 83-91.

Maldonado, A., 1979. Upper Cretaceous and Cenozoic depositional processes and facies in the distal North Atlantic continental margin off Portugal, DSDP Site 398. In Sibuet, J.-C., Ryan, W.B.F., et al., Init. Repts. DSDP, 47, Pt. 2: Washington (U.S. Govt. Printing Office), 373-401.

Mougenot, D., Vanney, J. R., Mauffret, A., and Kidd, R. B., 1985. Les montagnes sous-marins de la marge continentale nord-portugaise: morphologie et évolution structurale. Bull. Soc. Geol. Fr., 9:401412.

Nelsen, T. A., 1976. An automated rapid sediment analyser (ARSA). Sedimentology, 23:287-872.

Piper, D.J.W., 1978. Turbidite muds and silts on deep-sea fans and abyssal plains. In Stanley, D. J., and Kelling, G. (Eds.), Sedimentation in Submarine Canyons, Fans and Trenches: Stroudsburg, PA (Dowden, Hutchinson and Ross), 163-174.

Sarnthein, M., Theide, M. J., Pflaumann, H., Erlenkeuser, H., Futterer, D., Koopman, B., Lange, H., and Seibol, E., 1982. Atmospheric ocean circulation patterns off northwest Africa during the last 26 million years. In von Rad, U., Hinz, K., Sarnthein, M., and Seibol, E. (Eds.), The Geology of the Northwest African Continental Margin: New York (Springer-Verlag), 545-604.

Shepard, F. P., 1954. Nomenclature based on sand-silt-clay ratios. $J$. Sediment. Petrol., 24:151-158.

Shipboard Scientific Party, 1972a. Site 118. In Laughton, A. S., Berggren, W. A., et al., Init. Repts. DSDP, 12: Washington (U.S. Govt. Printing Office), 673-751.

Shipboard Scientific Party, 1972b. Site 119. In Laughton, A. S., Berggren, W. A., et al., Init. Repts. DSDP, 12: Washington (U.S. Govt. Printing Office), 753-899.

1979. Site 398. In von Rad, U., Ryan, W.B.F., et al, Init. Repts. DSDP, 47, Pt. 2: Washington (U.S. Govt. Printing Office), $25-233$.

1987. Site 637. In Boillot, G., Winterer, E. L., et al., Proc. $O D P$, Init. Repts., 103: College Station, TX (Ocean Drilling Program), 123-219.

Stow, D.A.V., 1979. Distinguishing between fine-grained turbidites and contourites on the Nova Scotia deep water margin. Sedimentology, 25:371-387.

1982. Bottom currents and contourites in the North Atlantic. Bull. Ins. Geol. Bassin Aquitaine, 31:151-166.

Stow, D.A.V., and Bowen, A. J., 1978. Origin of lamination on deepsea, fine-grained sediments. Nature, 274:324-328.

1980. Physical model for transport and sorting of finegrained sediment in turbidity currents. Sedimentology, 27:31-47.

Stow, D.A.V., and Holbrook, J. A., 1984. North Atlantic contourites: an overview. In Stow, D.A.V., and Piper, D.J.W. (Eds.), Fine-Grained Sediments: Deep-Water Processes and Facies: London (Blackwell), 245-256.

Stow, D.A.V., and Lowell, J.P.B., 1979. Contourites: their recognition in modern and ancient sediments. Earth Sci. Rev., 14:251-259.

Stow, D.A.V., and Piper, D.J.W., 1984. Deep-water fine-grained sediments: history methodology and terminology. In Stow, D.A.V., and Piper, D.J.W., (Eds.), Fine-Grained Sediments: Deep-Water Processes and Facies: London (Blackwell), 3-14.

Stow, D.A.V., and Shanmugam, E., 1980. Sequence of structures in fine-grained turbidites: comparison recent deep-sea and ancient flysch sediments. Sediment. Geol., 25:23-42.

van Andel, P.J.H., Thiede, J., Sclater, J. E., and Hay, W. W., 1977. Depositional history of the South Atlantic Ocean during the last 125 million years. J. Geol., 85:651-698.

Date of initial receipt: 10 April 1987

Date of acceptance: 27 October 1987

Ms 103B-132 
APPENDIX A

List of samples analyzed from Hole 637A, showing total carbonate content and facies type for each sample. Facies type symbols as in Table 1. $B$ = highly bioturbated sample.

\begin{tabular}{|c|c|c|c|}
\hline Code & $\begin{array}{l}\text { Sample (core, } \\
\text { section) }\end{array}$ & $\begin{array}{l}\text { Facies } \\
\text { type }\end{array}$ & $\mathrm{CO}_{3}(\%)$ \\
\hline 1 & $6 \mathrm{R}-2,6-8 \mathrm{~cm}$ & $\mathrm{~T}_{d}$ & 19.5 \\
\hline 33 & $6 \mathrm{R}-3,9-11 \mathrm{~cm}$ & $\mathrm{~T}_{e 2}$ & 11.2 \\
\hline 34 & $6 \mathrm{R}-3,28-30 \mathrm{~cm}$ & $\mathrm{~T}_{e 1}^{e t}$ & 15.6 \\
\hline 35 & $6 \mathrm{R}-3,124-126 \mathrm{~cm}$ & $\mathrm{P}^{\mathrm{e}}$ & 63.9 \\
\hline 2 & $7 \mathrm{R}-2,24-26 \mathrm{~cm}$ & FS & 75.5 \\
\hline 36 & $7 \mathrm{R}-2,46-48 \mathrm{~cm}$ & $\mathrm{P}$ & 73 \\
\hline 3 & $7 \mathrm{R}-2,83-85 \mathrm{~cm}$ & $\mathrm{FC}$ & 69.4 \\
\hline 4 & $7 \mathrm{R}-2,91-93 \mathrm{~cm}$ & $\mathrm{~T}_{d}$ & 19.4 \\
\hline 5 & $7 \mathrm{R}-2,110-112 \mathrm{~cm}$ & $\mathrm{~T}_{d}$ & 21.5 \\
\hline 37 & $8 \mathrm{R}-2,48-50 \mathrm{~cm}$ & $\mathrm{~T}_{d}$ & 28.3 \\
\hline 38 & $8 \mathrm{R}-2,66-68 \mathrm{~cm}$ & $\mathrm{~T}_{d}^{u}$ & 36.4 \\
\hline 39 & $8 \mathrm{R}-2,73-75 \mathrm{~cm}$ & $\mathrm{P}^{a}$ & 64.2 \\
\hline 40 & $8 \mathrm{R}-3,46-48 \mathrm{~cm}$ & $\mathrm{~T}_{e 3}$ & 19.3 \\
\hline 41 & $8 \mathrm{R}-3,51-53 \mathrm{~cm}$ & $\mathrm{~T}_{d}$ & 17.2 \\
\hline 42 & $8 \mathrm{R}-3,56-58 \mathrm{~cm}$ & $\mathrm{~T}_{c}^{u}$ & 15.7 \\
\hline 6 & $8 \mathrm{R}-3,62-64 \mathrm{~cm}$ & $\mathrm{P}^{c}$ & 54 \\
\hline 7 & $8 \mathrm{R}-3,74-76 \mathrm{~cm}$ & $\mathrm{~T}_{e 3}$ & 5.04 \\
\hline 8 & $8 \mathrm{R}-3,94-96 \mathrm{~cm}$ & $\mathrm{~T}_{d}$ & 10 \\
\hline 43 & $8 \mathrm{R}-3,102-104 \mathrm{~cm}$ & $F^{*}$ & 15 \\
\hline 44 & $8 \mathrm{R}-3,107-109 \mathrm{~cm}$ & $\mathrm{~T}_{e 1}$ & 23.8 \\
\hline 45 & $8 \mathrm{R}-3,112-114 \mathrm{~cm}$ & $\mathrm{FC}$ & 55.2 \\
\hline 9 & $9 \mathrm{R}-2,32-34 \mathrm{~cm}$ & $\mathrm{~T}_{d}$ & 14.3 \\
\hline 10 & $9 \mathrm{R}-2,44-46 \mathrm{~cm}$ & $\mathrm{~T}_{e 2}^{a}$ & 15.8 \\
\hline 46 & $9 \mathrm{R}-2,87-89 \mathrm{~cm}$ & $\mathrm{P}^{2 L}$ & 43.9 \\
\hline 47 & $10 \mathrm{R}-1,65-67 \mathrm{~cm}$ & $\mathrm{~T}_{e 3}$ & 23.9 \\
\hline 48 & $10 \mathrm{R}-1,102-104 \mathrm{~cm}$ & $\mathrm{P}^{e s}$ & 55 \\
\hline 11 & $10 \mathrm{R}-1,114-116 \mathrm{~cm}$ & $\mathbf{T}_{e 3}$ & 25.1 \\
\hline 49 & $11 \mathrm{R}-1,41-43 \mathrm{~cm}$ & $\mathrm{~T}_{e 3}$ & 5.96 \\
\hline 50 & $11 \mathrm{R}-1,77-79 \mathrm{~cm}$ & $\mathrm{~F}^{\mathrm{s}}$ & 28.4 \\
\hline 51 & $11 \mathrm{R}-1,106-108 \mathrm{~cm}$ & $\mathrm{~T}_{d}$ & 12 \\
\hline 12 & $11 \mathrm{R}-1,114-116 \mathrm{~cm}$ & $\mathrm{~T}_{e 1}^{a}$ & 28.7 \\
\hline 52 & $11 \mathrm{R}-1,122-124 \mathrm{~cm}$ & B & 40 \\
\hline 13 & $12 \mathrm{R}-1,87-89 \mathrm{~cm}$ & $\mathbf{T}_{d}$ & 12.9 \\
\hline 53 & $12 \mathrm{R}-2,45-47 \mathrm{~cm}$ & $\mathrm{~T}_{e 3}^{u}$ & 6.76 \\
\hline 54 & $12 \mathrm{R}-2,56-58 \mathrm{~cm}$ & $\mathrm{~T}_{d}$ & 12.7 \\
\hline 55 & $12 \mathrm{R}-2,76-78 \mathrm{~cm}$ & $\mathrm{~T}_{e 3}^{u}$ & 4.49 \\
\hline 56 & $12 \mathrm{R}-2,91-93 \mathrm{~cm}$ & $F^{e s}$ & 44.8 \\
\hline 57 & $12 \mathrm{R}-2,95-97 \mathrm{~cm}$ & $P$ & 44.7 \\
\hline 58 & $13 \mathrm{R}-1,92-94 \mathrm{~cm}$ & $\mathbf{P}$ & 25.4 \\
\hline 59 & $13 \mathrm{R}-1,95-97 \mathrm{~cm}$ & $\mathrm{~T}_{e 3}$ & 6.7 \\
\hline 60 & $13 \mathrm{R}-1,101-103 \mathrm{~cm}$ & $\mathrm{~T}_{d}$ & 6.7 \\
\hline 61 & $13 \mathrm{R}-2,41-43 \mathrm{~cm}$ & $\mathrm{~T}_{d}$ & 18.7 \\
\hline 62 & $13 \mathrm{R}-2,47-49 \mathrm{~cm}$ & $\mathrm{P}^{a}$ & 56.7 \\
\hline 63 & $13 \mathrm{R}-2,59-61 \mathrm{~cm}$ & $\mathrm{~F}$ & 40.3 \\
\hline 64 & $13 \mathrm{R}-2,64-66 \mathrm{~cm}$ & $\mathrm{~T}_{d}$ & 15.7 \\
\hline 14 & $13 \mathrm{R}-2,86-88 \mathrm{~cm}$ & $\mathrm{~T}_{d}^{a}$ & 21.6 \\
\hline 65 & $14 \mathrm{R}-1,5-7 \mathrm{~cm}$ & $F^{a}$ & 46.7 \\
\hline 66 & $14 \mathrm{R}-1,15-17 \mathrm{~cm}$ & $\mathrm{~T}_{e 2}$ & 10.5 \\
\hline 15 & $14 \mathrm{R}-1,67-69 \mathrm{~cm}$ & $\mathrm{~T}_{d} e^{2}$ & 10.1 \\
\hline 67 & $14 \mathrm{R}-1,115-117 \mathrm{~cm}$ & $\mathrm{~T}_{e 3}$ & 16.4 \\
\hline 68 & $14 \mathrm{R}-2,5-7 \mathrm{~cm}$ & $\mathbf{P}$ & 58.2 \\
\hline 69 & $15 \mathrm{R}-1,41-43 \mathrm{~cm}$ & F & 29 \\
\hline 70 & $15 \mathrm{R}-1,54-56 \mathrm{~cm}$ & $\mathrm{~T}_{d}$ & 17.1 \\
\hline 71 & $15 \mathrm{R}-1,83-85 \mathrm{~cm}$ & $\mathrm{~B}$ & 24.5 \\
\hline 16 & $15 \mathrm{R}-1,111-113 \mathrm{~cm}$ & $\mathrm{~T}_{d}$ & 15.8 \\
\hline 72 & $15 \mathrm{R}-1,117-119 \mathrm{~cm}$ & $\mathrm{P}$ & 63.9 \\
\hline 73 & $15 \mathrm{R}-2,67-69 \mathrm{~cm}$ & $\mathrm{~T}_{d}$ & 14.3 \\
\hline 17 & $15 \mathrm{R}-2,76-78 \mathrm{~cm}$ & $\mathrm{~T}_{d}^{a}$ & 17.9 \\
\hline 74 & $15 \mathrm{R}-2,84-86 \mathrm{~cm}$ & $P$ & 49.1 \\
\hline 75 & $15 \mathrm{R}-2,115-117 \mathrm{~cm}$ & $\mathrm{~T}_{c}$ & 32.5 \\
\hline 76 & $15 \mathrm{R}-3,129-131 \mathrm{~cm}$ & $\mathrm{P}$ & 70.7 \\
\hline 77 & $15 \mathrm{R}-4,73-75 \mathrm{~cm}$ & $\mathrm{P}$ & 63.2 \\
\hline 78 & $16 \mathrm{R}-1,24-26 \mathrm{~cm}$ & $\mathrm{~T}_{e 2}$ & 30 \\
\hline 79 & $15 \mathrm{R}-2,22-24 \mathrm{~cm}$ & $\mathrm{~T}_{e 3}$ & 48.2 \\
\hline 80 & $15 \mathrm{R}-2,36-38 \mathrm{~cm}$ & $\mathrm{~T}_{e 2}$ & 13.6 \\
\hline 81 & $16 \mathrm{R}-1,80-82 \mathrm{~cm}$ & $\mathrm{~T}_{e 1}^{2 \mathrm{z}}$ & 20.3 \\
\hline 82 & $16 \mathrm{R}-2,22-24 \mathrm{~cm}$ & $\mathrm{P}^{e x}$ & 70.9 \\
\hline 83 & $16 \mathrm{R}-2,135-137 \mathrm{~cm}$ & $\mathrm{~F}$ & 42.3 \\
\hline 84 & $16 \mathrm{R}-2,144-146 \mathrm{~cm}$ & $\mathrm{~T}_{d}$ & 21.2 \\
\hline 85 & $16 \mathrm{R}-3,3-5 \mathrm{~cm}$ & $\mathrm{~T}_{e 1}$ & 22.6 \\
\hline 18 & $16 \mathrm{R}-3,58-60 \mathrm{~cm}$ & $\mathrm{~T}_{e 1}$ & 18.7 \\
\hline 86 & $16 \mathrm{R}-3,66-68 \mathrm{~cm}$ & $\mathrm{~T}_{e 2}$ & 18.9 \\
\hline 87 & $16 \mathrm{R}-4,6-8 \mathrm{~cm}$ & $\mathrm{~F}^{22}$ & 15.8 \\
\hline 88 & $17 \mathrm{R}-1,24-26 \mathrm{~cm}$ & $\mathrm{~T}_{e 2}$ & 10.5 \\
\hline
\end{tabular}

Appendix A (continued).

\begin{tabular}{|c|c|c|c|}
\hline Code & $\begin{array}{l}\text { Sample (core, } \\
\text { section) }\end{array}$ & $\begin{array}{l}\text { Facies } \\
\text { type }\end{array}$ & $\mathrm{CO}_{3}(\%)$ \\
\hline 19 & $17 \mathrm{R}-1,52-54 \mathrm{~cm}$ & $\mathrm{~T}_{d}$ & 9.36 \\
\hline 20 & $17 \mathrm{R}-1,62-64 \mathrm{~cm}$ & $\mathrm{~T}_{d}^{a}$ & 7.2 \\
\hline 89 & $17 \mathrm{R}-1,67-69 \mathrm{~cm}$ & $\mathrm{~T}_{d}^{a}$ & 6.04 \\
\hline 90 & $17 \mathrm{R}-1,90-92 \mathrm{~cm}$ & $\mathrm{~T}_{e 3}$ & 29.4 \\
\hline 91 & $17 \mathrm{R}-1,113-115 \mathrm{~cm}$ & $\mathrm{~T}_{d}^{e 3}$ & 13.6 \\
\hline 92 & $17 \mathrm{R}-1,126-128 \mathrm{~cm}$ & $\mathrm{~T}_{e 2}^{a}$ & 19.6 \\
\hline 93 & $17 \mathrm{R}-1,134-136 \mathrm{~cm}$ & $\mathrm{~T}_{e 3}^{e L}$ & 28.6 \\
\hline 21 & $17 \mathrm{R}-2,4-6 \mathrm{~cm}$ & $\mathrm{~T}_{d}$ & 20.2 \\
\hline 94 & $17 \mathrm{R}-2,10-12 \mathrm{~cm}$ & $P^{u}$ & 60.4 \\
\hline 95 & $17 \mathrm{R}-2,27-29 \mathrm{~cm}$ & $\mathbf{P}$ & 61.1 \\
\hline 96 & $17 \mathrm{R}-2,43-45 \mathrm{~cm}$ & $\mathbf{P}$ & 29.3 \\
\hline 97 & $17 \mathrm{R}-2,85-87 \mathrm{~cm}$ & DC & 33.2 \\
\hline 98 & $17 \mathrm{R}-2,114-116 \mathrm{~cm}$ & FC & 74 \\
\hline 99 & $17 \mathrm{R}-2,146-148 \mathrm{~cm}$ & FC & 54.1 \\
\hline 100 & $17 \mathrm{R}-3,73-75 \mathrm{~cm}$ & $\mathrm{~T}_{e 3}$ & 31.6 \\
\hline 101 & $17 \mathrm{R}-3,123-125 \mathrm{~cm}$ & $\mathrm{P}^{e 3}$ & 66.2 \\
\hline 22 & $17 \mathrm{R}-4,115-117 \mathrm{~cm}$ & $\mathrm{~T}_{d}$ & 27.2 \\
\hline 102 & $18 \mathrm{R}-1,15-17 \mathrm{~cm}$ & $\mathrm{CC}$ & 33 \\
\hline 23 & $18 \mathrm{R}-1,57-59 \mathrm{~cm}$ & SS & 33.8 \\
\hline 24 & $18 \mathrm{R}-1,73-75 \mathrm{~cm}$ & FC & 76 \\
\hline 103 & $18 \mathrm{R}-1,113-115 \mathrm{~cm}$ & $\mathrm{CC}$ & 11.3 \\
\hline 104 & $18 \mathrm{R}-2,20-22 \mathrm{~cm}$ & $\mathrm{CC}$ & 29.4 \\
\hline 105 & $18 \mathrm{R}-2,72-74 \mathrm{~cm}$ & $\mathrm{CC}$ & 14.3 \\
\hline 106 & $18 \mathrm{R}-2,94-96 \mathrm{~cm}$ & MC & 15.8 \\
\hline 107 & $18 \mathrm{R}-2,102-104 \mathrm{~cm}$ & MC & 12.1 \\
\hline 108 & $18 \mathrm{R}-2,107-109 \mathrm{~cm}$ & MC & 8.28 \\
\hline 109 & $18 \mathrm{R}-2,89-91 \mathrm{~cm}$ & $\mathrm{SC}$ & 29.4 \\
\hline 110 & $19 \mathrm{R}-1,51-53 \mathrm{~cm}$ & $\mathrm{SC}$ & 12.1 \\
\hline 111 & $19 \mathrm{R}-1,137-139 \mathrm{~cm}$ & $\mathrm{MC}$ & 12.8 \\
\hline 112 & $19 \mathrm{R}-2,13-15 \mathrm{~cm}$ & SC & 17.2 \\
\hline 113 & $19 \mathrm{R}-2,31-33 \mathrm{~cm}$ & $\mathrm{SC}$ & 20.4 \\
\hline 114 & $19 \mathrm{R}-2,144-146 \mathrm{~cm}$ & $\mathrm{MC}$ & 15.8 \\
\hline 115 & $19 \mathrm{R}-3,5-7 \mathrm{~cm}$ & $\mathrm{MC}$ & 14 \\
\hline 116 & $19 \mathrm{R}-3,14-16 \mathrm{~cm}$ & $\mathrm{P}$ & 79.4 \\
\hline 117 & $20 \mathrm{R}-1,24-26 \mathrm{~cm}$ & $\mathrm{SC}$ & 18.7 \\
\hline 118 & $20 \mathrm{R}-1,28-30 \mathrm{~cm}$ & $\mathrm{SC}$ & 66.7 \\
\hline 119 & $20 \mathrm{R}-1,52-54 \mathrm{~cm}$ & $\mathrm{FC}^{\prime}$ & 71.6 \\
\hline 120 & $20 \mathrm{R}-1,74-76 \mathrm{~cm}$ & $\mathrm{CC}$ & 6.23 \\
\hline 121 & $20 \mathrm{R}-1,135-137 \mathrm{~cm}$ & $\mathrm{CC}$ & 5.44 \\
\hline
\end{tabular}


APPENDIX B

Alkali elements and heavy metal contents in selected Hole 637A samples. Codes as in Appendix A.

\begin{tabular}{rrrrrrrrrr}
\hline Code & $\begin{array}{c}\mathrm{Ni} \\
(\mathrm{ppm})\end{array}$ & $\begin{array}{c}\mathrm{Cu} \\
(\mathrm{ppm})\end{array}$ & $\begin{array}{c}\mathrm{Pb} \\
(\mathrm{ppm})\end{array}$ & $\begin{array}{r}\mathrm{Co} \\
(\mathrm{ppm})\end{array}$ & $\begin{array}{r}\mathrm{Ca} \\
(\%)\end{array}$ & $\begin{array}{c}\mathrm{Mg} \\
(\%)\end{array}$ & $\begin{array}{c}\mathrm{Sr} \\
(\mathrm{ppm})\end{array}$ & $\begin{array}{c}\mathrm{Fe} \\
(\%)\end{array}$ & $\begin{array}{c}\mathrm{Mn} \\
(\mathrm{ppm})\end{array}$ \\
\hline 1 & 44.92 & 25.02 & 15.89 & 10.19 & 6.90 & 0.72 & 204.67 & 10.50 & 159.58 \\
2 & 20.33 & 27.16 & 41.62 & 18.44 & 28.86 & 0.33 & 1394.48 & 5.25 & 580.13 \\
3 & 18.28 & 8.78 & 36.94 & 14.32 & 31.20 & 0.60 & 865.88 & 5.71 & 309.95 \\
4 & 11.79 & 12.55 & 27.59 & 13.14 & 8.70 & 0.87 & 204.67 & 0.11 & 154.30 \\
5 & 18.96 & 9.76 & 696.89 & 5.77 & 8.25 & 0.93 & 248.75 & 13.48 & 171.45 \\
6 & 21.35 & 14.36 & 38.11 & 7.54 & 20.43 & 0.60 & 865.88 & 9.98 & 462.96 \\
7 & 22.72 & 26.83 & 29.93 & 11.37 & 1.11 & 1.14 & 50.38 & 19.67 & 200.47 \\
8 & 18.28 & 12.72 & 22.91 & 8.42 & 4.08 & 0.87 & 72.42 & 16.43 & 225.53 \\
9 & 22.78 & 10.91 & 521.47 & 8.42 & 5.19 & 0.72 & 160.59 & 17.58 & 230.81 \\
10 & 55.50 & 23.71 & 32.27 & 13.43 & 6.03 & 0.87 & 204.67 & 15.22 & 378.54 \\
11 & 19.65 & 27.16 & 34.60 & 9.31 & 9.72 & 0.81 & 403.03 & 14.04 & 189.92 \\
12 & 26.14 & 43.89 & 43.96 & 12.84 & 12.99 & 0.78 & 425.07 & 11.02 & 246.53 \\
13 & 54.82 & 16.16 & 21.74 & 21.98 & 4.29 & 1.02 & 94.47 & 22.24 & 2110.23 \\
14 & 33.99 & 16.00 & 111.79 & 14.02 & 7.53 & 0.57 & 292.83 & 12.34 & 259.82 \\
15 & 20.67 & 16.98 & 59.16 & 9.60 & 2.48 & 0.85 & 116.51 & 19.55 & 619.70 \\
16 & 20.33 & 11.73 & 19.40 & 8.53 & 6.03 & 1.44 & 204.67 & 18.40 & 337.65 \\
17 & 25.79 & 12.72 & 88.77 & 11.37 & 5.31 & 0.69 & 160.59 & 17.02 & 349.52 \\
18 & 23.74 & 27.81 & 32.27 & 9.60 & 6.51 & 0.54 & 248.75 & 14.83 & 302.04 \\
19 & 24.43 & 17.51 & 31.10 & 12.84 & 2.73 & 0.57 & 116.51 & 21.68 & 1266.03 \\
20 & 13.50 & 11.57 & 17.06 & 7.24 & 1.32 & 0.45 & 72.43 & 14.63 & 354.80 \\
21 & 45.26 & 17.47 & 139.86 & 19.03 & 8.16 & 0.66 & 314.87 & 12.73 & 185.96 \\
22 & 16.23 & 11.90 & 19.40 & 8.13 & 10.11 & 0.66 & 336.91 & 7.29 & 315.22 \\
23 & 24.43 & 16.49 & 31.10 & 11.96 & 12.54 & 0.54 & 447.11 & 6.70 & 685.65 \\
24 & 27.16 & 12.06 & 52.15 & 16.38 & 25.77 & 0.33 & 932.00 & 4.40 & 1358.37 \\
\hline & & & & & & & & &
\end{tabular}




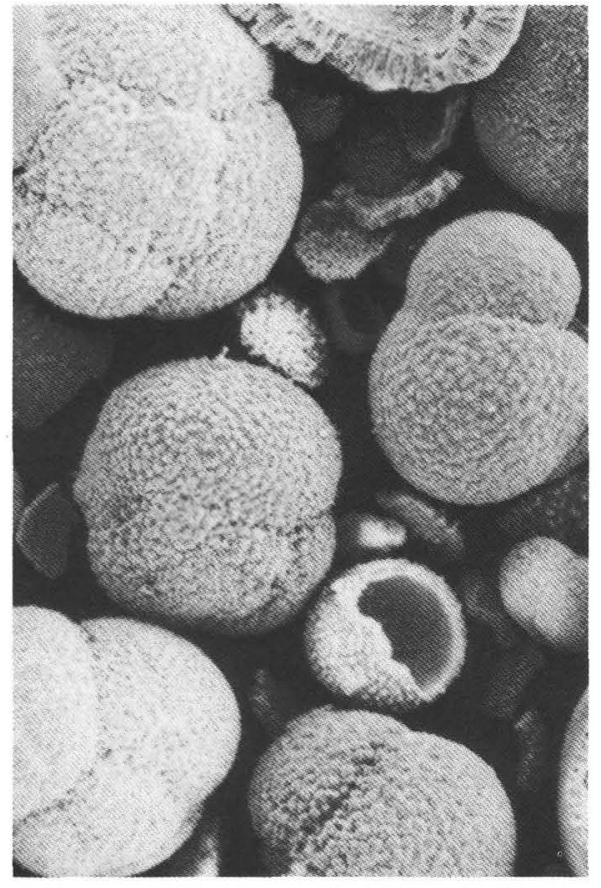

1

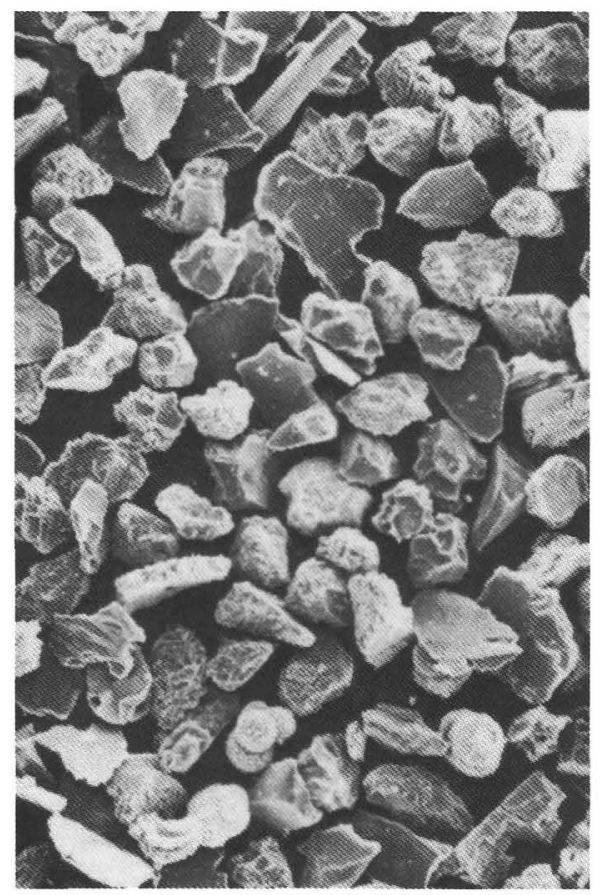

4

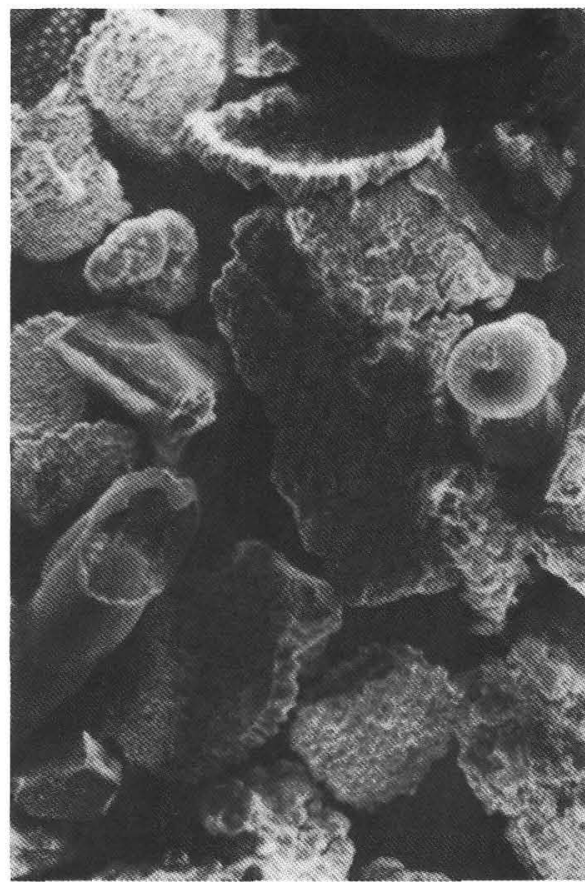

2

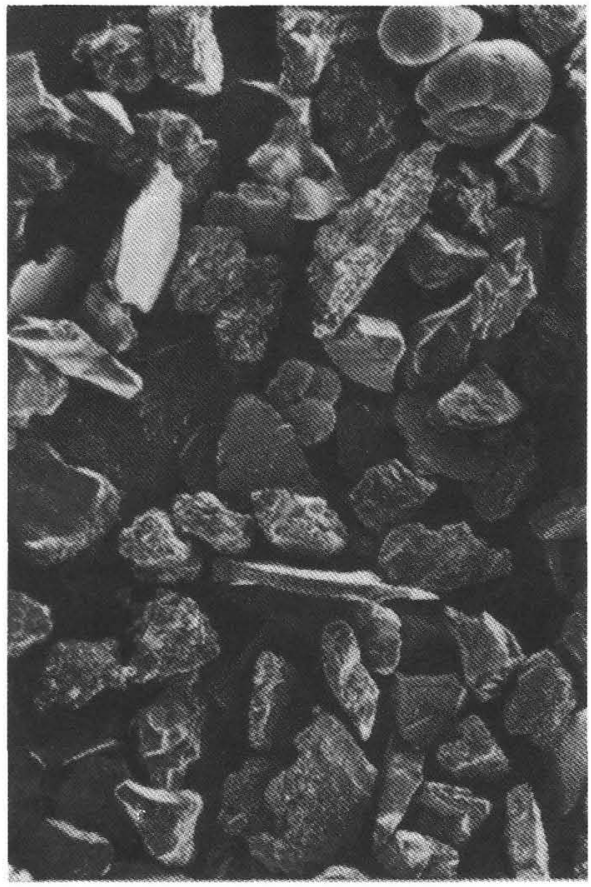

5

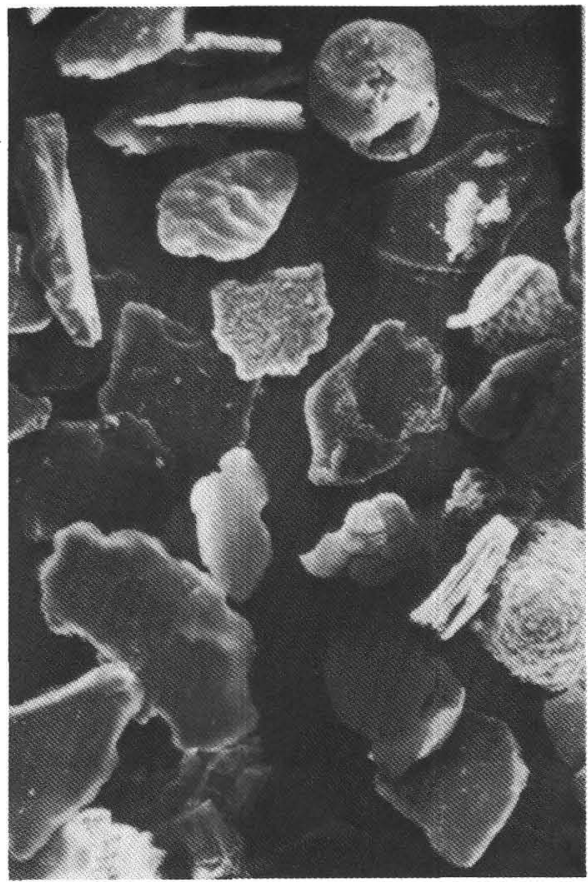

3

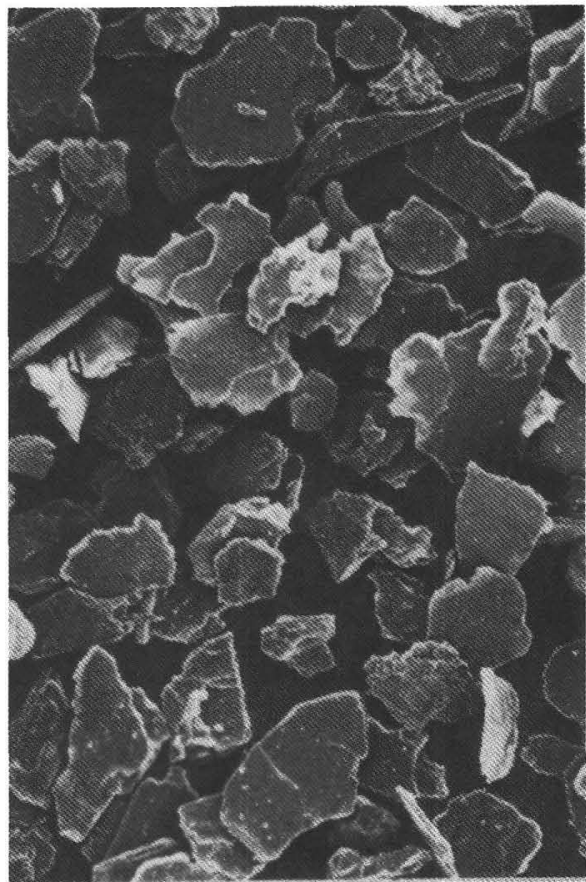

6

$100 \mu \mathrm{m}$

Plate 1. SEM photomicrographs of the sand-size fraction from pelagite and turbidite facies. 1. Upper Pliocene biogenic pelagite, with well- and moderately preserved planktonic foraminifers. Sample 103-637A-13R-2, 47-49 cm. 2. Upper Pliocene hemipelagite, with benthic and fragmented planktonic foraminifers. Sample 103-637A-13R-2, 59-61 cm. 3. Lower Pleistocene $\mathrm{T}_{e 1}$ division turbidite facies. Note fine micas, minor quartz, and benthic and planktonic foraminifers. Sample 103-637A-8R-3, 107-109 cm. 4. Lower Pleistocene $\mathrm{T}_{d}$ division turbidite facies. Note quartz, mica, and foraminifer fragments. Sample 103-637A-9R-2, 32-34 cm. 5. Upper Pliocene $\mathrm{T}_{d}$ division turbidite facies. Note quartz, dolomite fragments, mica, and benthic and planktonic whole foraminifers. Sample 103-637A-13R-2, 41-43 cm. 6. Lower Pliocene $T_{d}$ division turbidite facies composed of mica. Sample 103-637A-17R-1, 62-64 cm. 


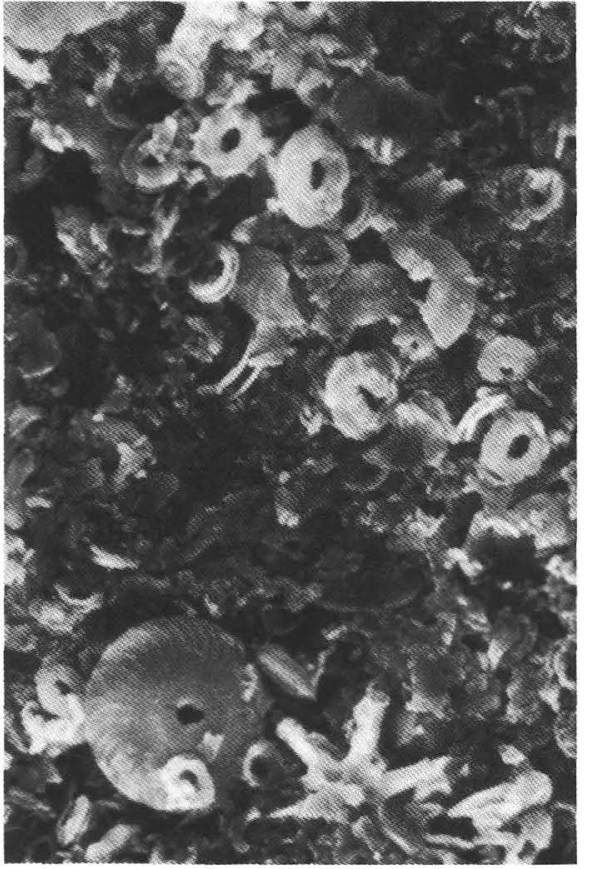

1

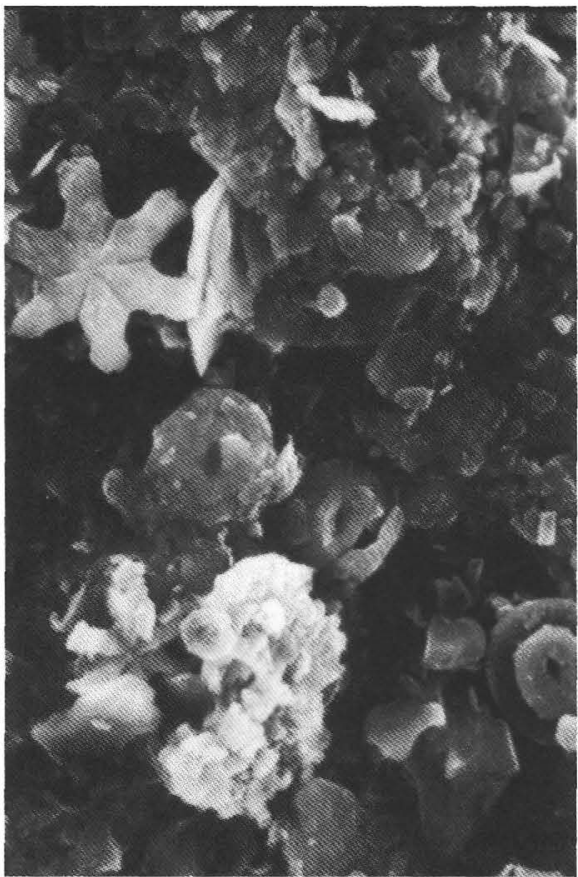

4

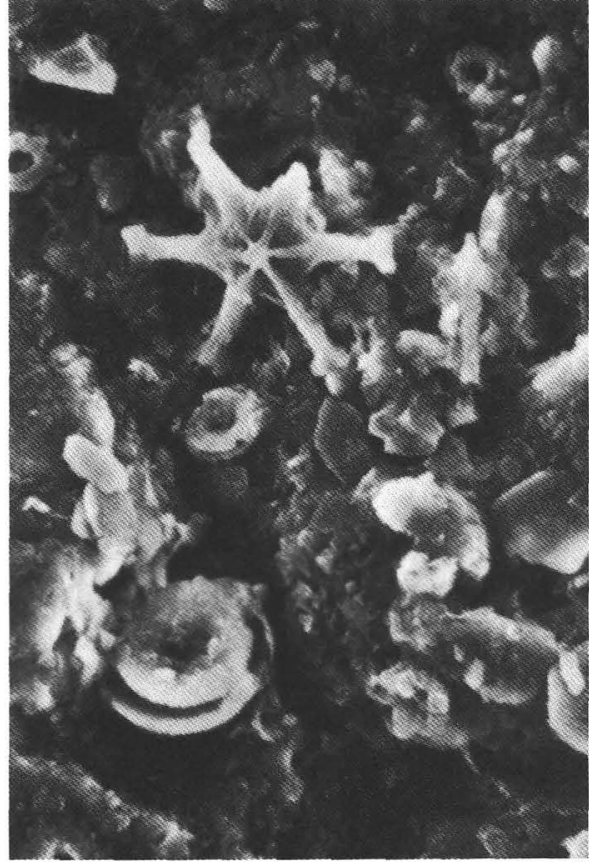

2

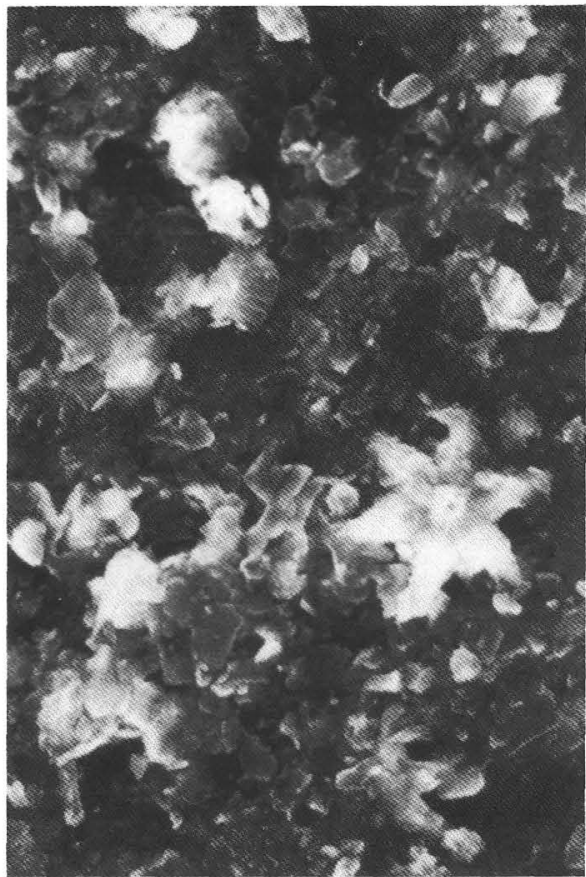

5

$5 \mu \mathrm{m}$

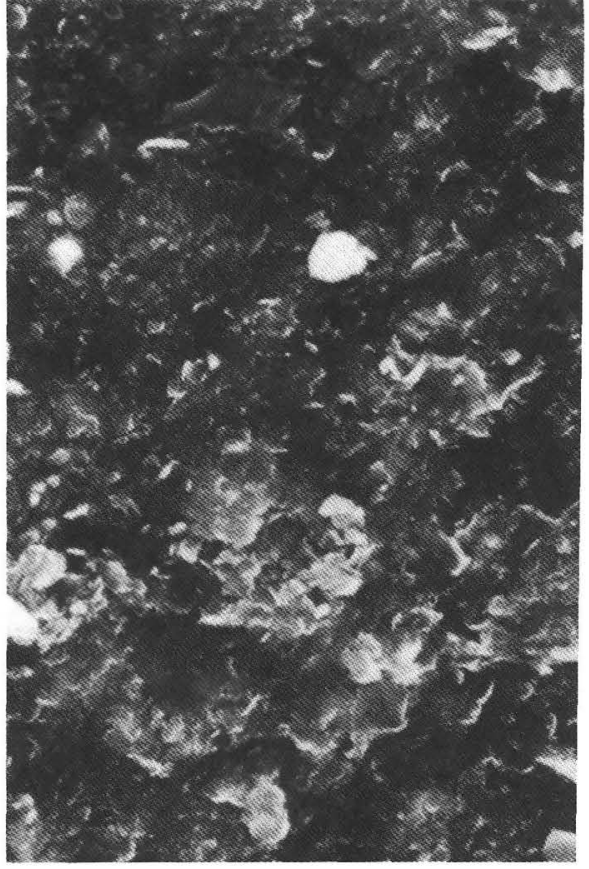

3

$5 \mu n$

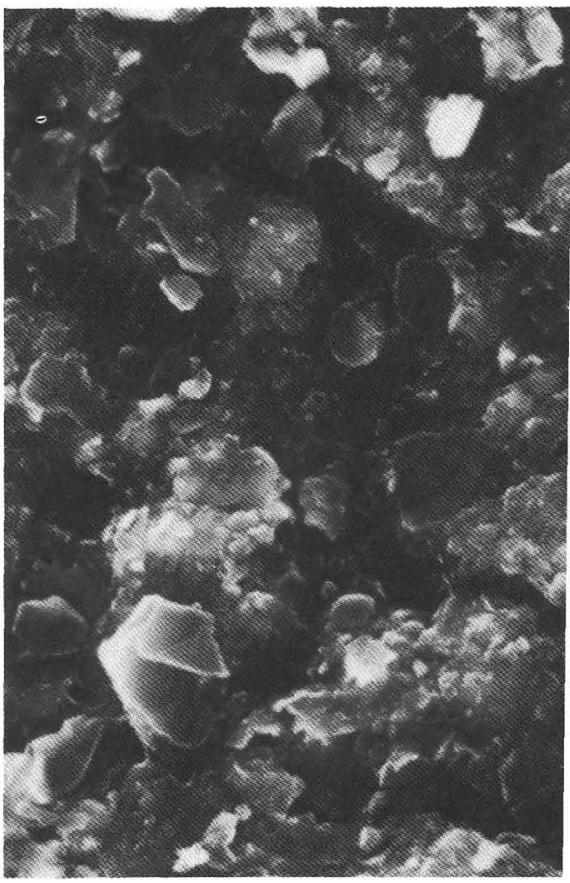

6

Plate 2. SEM photomicrographs of silt- and clay-size fraction from pelagite, turbidite, and contourite facies. 1. Lower Pliocene biogenic pelagite containing abundant and well- to moderately preserved nannofossils. Sample 103-637A-17R-2, 27-29 cm. 2. Lower Pliocene hemipelagite, with clay, mica, and moderately preserved nannofossils. Sample 103-637A-16R-4, 6-8 cm. 3. $\mathrm{T}_{e 3}$ division. Note clay minerals and the absence of nannofossils. Sample 103-637A-11R-1, 41-43 cm. 4. Upper Miocene silt contourites. Nannofossils are poorly preserved. Sample 103-637A-20R-1, 28-30 $\mathrm{cm}$. 5. Upper Miocene mud contourites. Note abundant clay mineral, micas, and minor poorly preserved nannofossils. Sample 103-637A-18R-2, 107-109 cm. 6. Upper Miocene clay contourite; nannofossils are absent. Sample 103-637A-20R-1, 74-76 cm. 

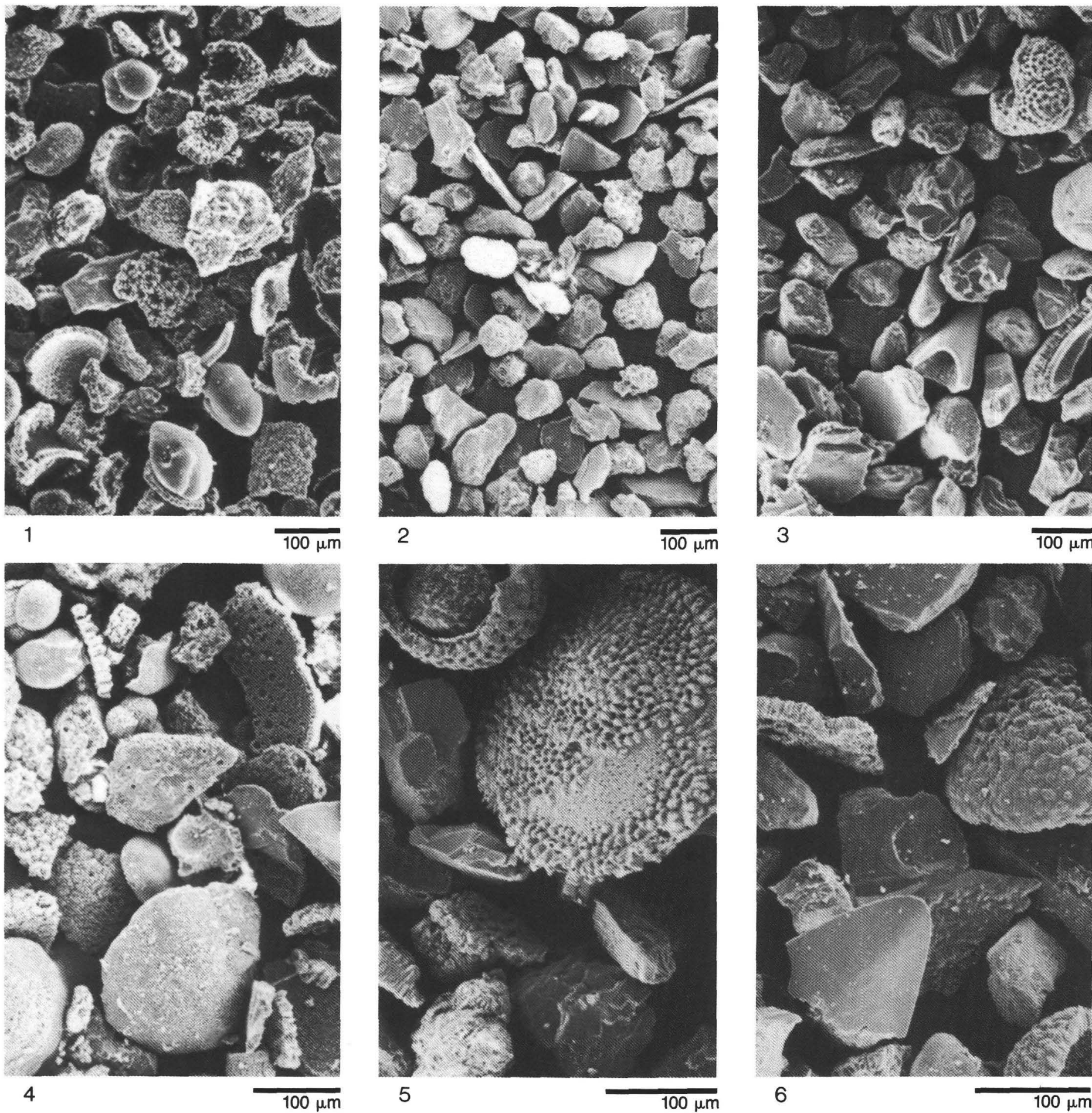

3

$100 \mu \mathrm{m}$

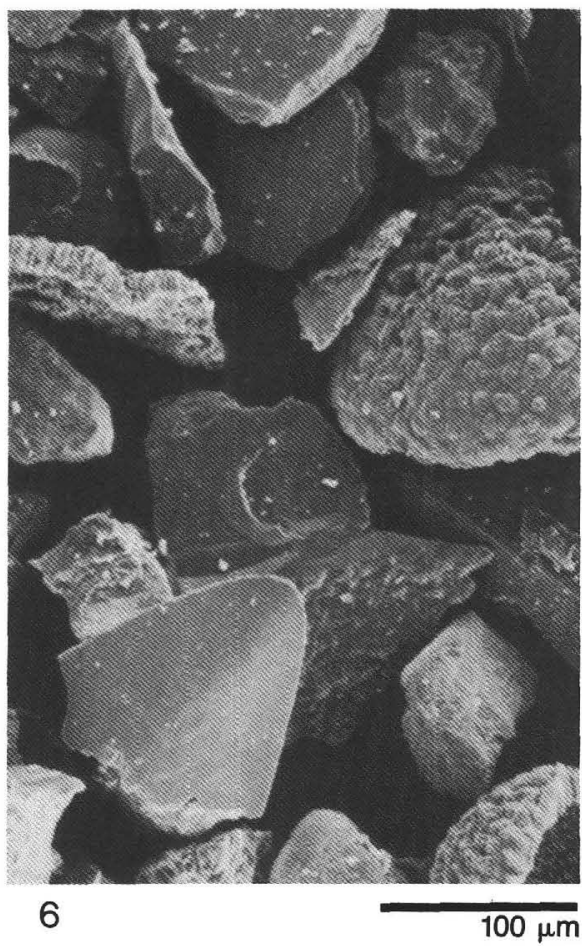

Plate 3. SEM photomicrographs of sand-size fraction from contourite facies. 1. Lower Pliocene contourite. Note poor preservation of foraminifers. Sample 103-637A-17R-2, 114-116 cm. 2. Upper Miocene silt contourite, containing quartz, mica, and eroded foraminifer fragments. Sample 103-637A-20R-1, 24-26 cm. 3. Upper Miocene mud contourite. Note quartz, mica, foraminifer fragment, and fish tooth. Sample 103-637A-18R-2, $107-109 \mathrm{~cm}$. 4. Pleistocene foraminiferal contourite showing poorly preserved benthic and broken planktonic foraminifers. Sample 103-637A-7R-2, 24-26 cm. 5. Upper Miocene silt contourite showing dissolution effects in foraminifers. Sample 103-637A-19R-1, 51-57 cm. 6. Upper Miocene clay contourite, with fish tooth and poorly preserved benthic and planktonic foraminifers. Sample 103-637A-18R-1, 15-17 cm. 